\title{
Expression and characterization of SARS-CoV-2 spike proteins
}

\author{
Jeffrey M. Schaub ${ }^{1,5}$, Chia-Wei Chou $\oplus^{1,5}$, Hung-Che Kuo ${ }^{1,5}$, Kamyab Javanmardi ${ }^{1,5}$, \\ Ching-Lin Hsieh ${ }^{1}{ }^{1}$, Jory Goldsmith ${ }^{1}$, Andrea M. DiVenere ${ }^{2}$, Kevin C. Le ${ }^{2}{ }^{2}$, Daniel Wrapp ${ }^{1}$, \\ Patrick O. Byrne $\mathbb{1}^{1}$, Christy K. Hjorth $\oplus^{1}$, Nicole V. Johnson $\oplus^{1}$, John Ludes-Meyers ${ }^{1}$, \\ Annalee W. Nguyen $\mathbb{(}^{2}$, Nianshuang Wang ${ }^{1}$, Jason J. Lavinder ${ }^{1,2}$, Gregory C. Ippolito $\circledast^{1,3}$,

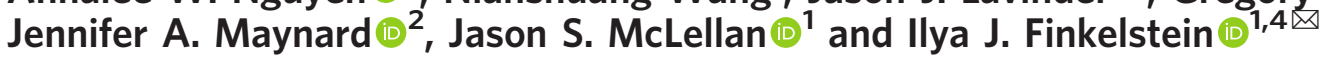

The severe acute respiratory syndrome coronavirus 2 spike protein is a critical component of coronavirus disease 2019 vaccines and diagnostics and is also a therapeutic target. However, the spike protein is difficult to produce recombinantly because it is a large trimeric class I fusion membrane protein that is metastable and heavily glycosylated. We recently developed a prefusion-stabilized spike variant, termed HexaPro for six stabilizing proline substitutions, that can be expressed with a yield of $>30 \mathrm{mg} / \mathrm{L}$ in ExpiCHO cells. This protocol describes an optimized workflow for expressing and biophysically characterizing rationally engineered spike proteins in Freestyle 293 and ExpiCHO cell lines. Although we focus on HexaPro, this protocol has been used to purify over a hundred different spike variants in our laboratories. We also provide guidance on expression quality control, long-term storage, and uses in enzyme-linked immunosorbent assays. The entire protocol, from transfection to biophysical characterization, can be completed in $\mathbf{7} \mathrm{d}$ by researchers with basic tissue cell culture and protein purification expertise.

The coronavirus disease 2019 (COVID-19) pandemic is a global health emergency that has resulted in over four million deaths as of summer 2021. The causative agent of COVID-19 is severe acute respiratory syndrome coronavirus 2 (SARS-CoV-2), a coronavirus-family RNA virus. SARS-CoV-2 encodes at least 12 canonical open reading frames in its 29.9 kilobase RNA genome ${ }^{1,2}$. Viral RNA is initially translated into two polyproteins with subsequent expression of multiple subgenomic mRNAs that are further processed into smaller proteins by virally encoded proteases ${ }^{3}$. Mature virions include spike (S), the nucleocapsid protein $(\mathrm{N})$, an ion channel (E) and an integral membrane protein (M). Spike is the most immunogenic of these proteins in other coronaviruses and is thus a major focus for vaccine, therapeutic and diagnostic development ${ }^{4-6}$.

Spike is a transmembrane homotrimeric class I fusion protein. Each virion is decorated with an average of $25-50$ spike trimers ${ }^{7-10}$ per virion, although other coronaviruses possess $\sim 90$ trimers $^{11}$. Spike mediates host cell entry by binding the cell angiotensin-converting enzyme 2 (ACE2) receptor and by subsequent virion-host membrane fusion. ACE2 is recognized by the spike receptor-binding domain (RBD) in the up conformation, located within the S1 subunit of the spike protein. Membrane fusion is enhanced by spike cleavage at the furin site separating the S1 and S2 domains and further increasing RBD-open states ${ }^{12-14}$. Furthermore, cleavage at the furin site increases SARS-CoV-2 infectivity ${ }^{12,15,16}$. A second cleavage within the S2 subdomain may further enhance infectivity via exposure of the fusion peptide (FP) necessary for viral entry, similar to SARS-CoV-1 $1^{17,18}$.

Spike is the first structural SARS-CoV-2 protein to be deposited in the protein data bank ${ }^{19}$. Early structures provided a glimpse of the prefusion complex in two conformations. In one view, the three RBDs were all pointing down (closed state, Fig. 1b); and in another view, one RBD was pointing up (partially open state $)^{20}$. Subsequent structures mapped out the dynamic nature of the three RBD domains (Fig. 1c) , $^{7,2}$. Structures of the isolated RBD alone and trimeric spike in complex with ACE2

${ }^{1}$ Department of Molecular Biosciences, The University of Texas at Austin, Austin, TX, USA. ${ }^{2}$ Department of Chemical Engineering, The University of Texas at Austin, Austin, TX, USA. ${ }^{3}$ Department of Oncology, Dell Medical School, The University of Texas at Austin, Austin, TX, USA. ${ }^{4}$ Center for Systems and Synthetic Biology, The University of Texas at Austin, Austin, TX, USA. ${ }^{5}$ These authors contributed equally: Jeffrey M. Schaub, Chia-Wei

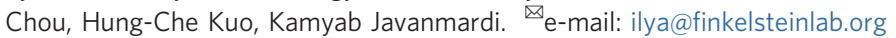


a

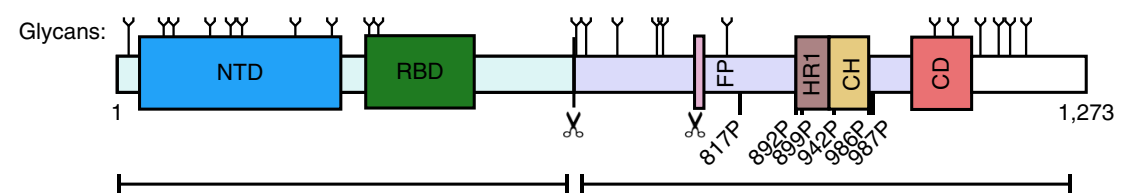

S1

S2

b
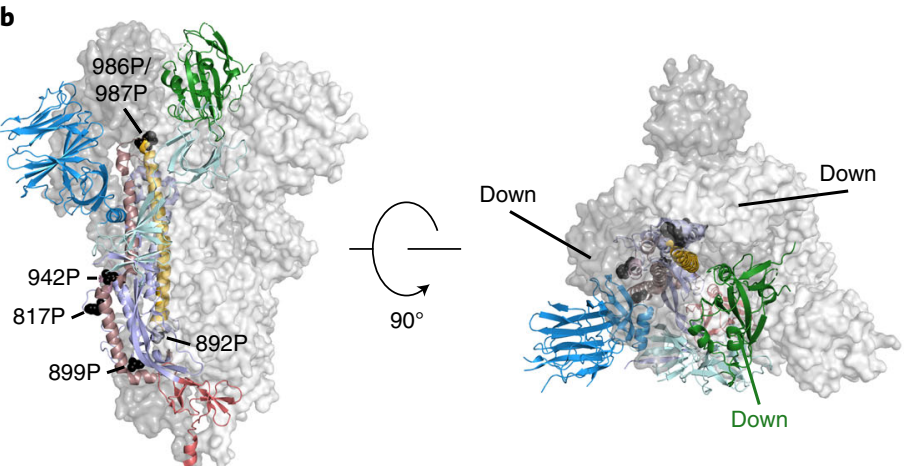

d
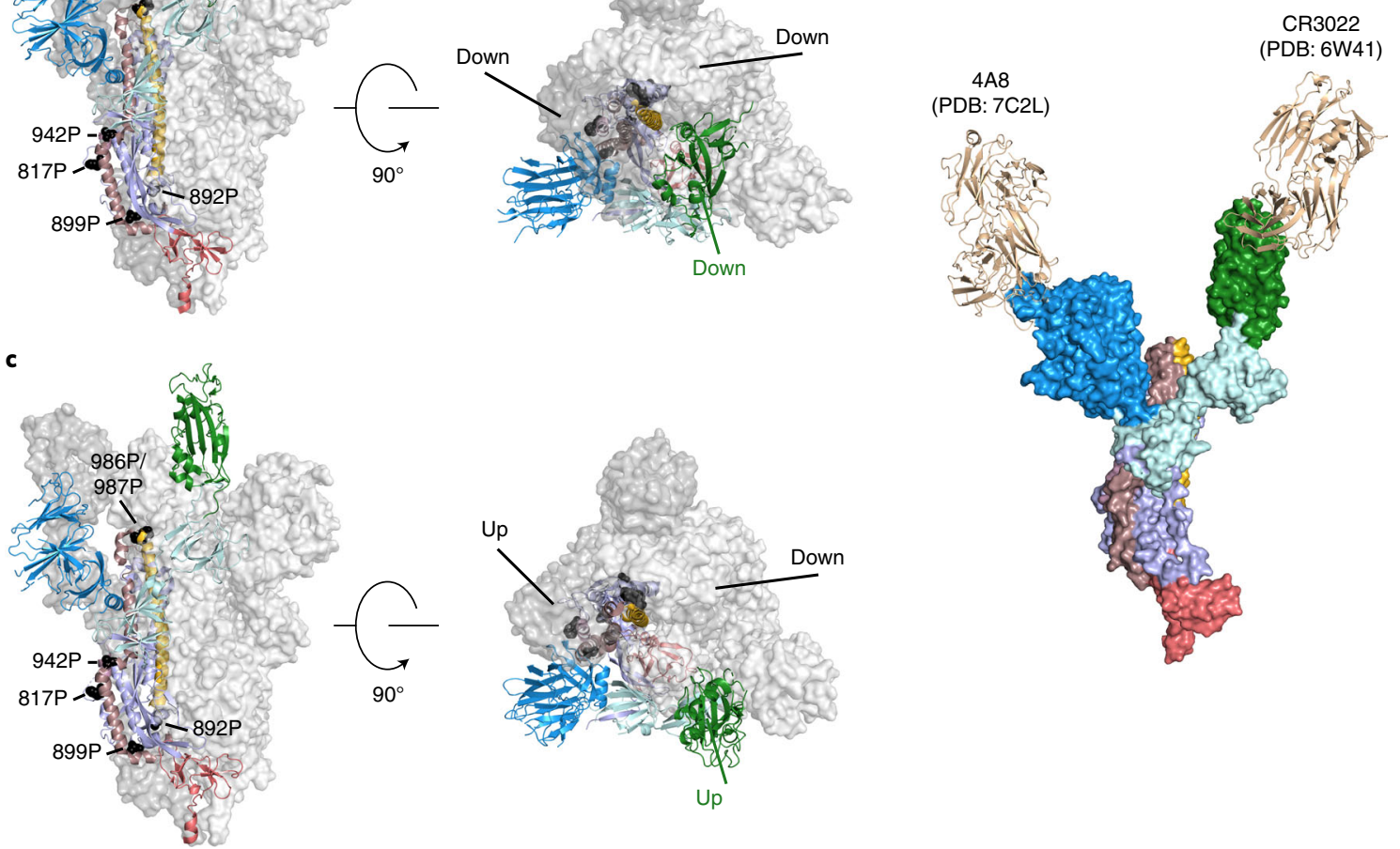

Fig. 1 | Overview of SARS-CoV-2 spike structure and antigenicity. a, Schematic of the SARS-CoV-2 spike domains subdivided by color. NTD, $\mathrm{N}$-terminal domain; RBD, receptor-binding domain; FP, fusion peptide; $H R 1$, heptad repeat 1; $C H$, central helix; $C D$, connector domain. White region is unresolved in cryo-EM structures of the ectodomain. Glycan positions noted on top of the primary structure as previously reported ${ }^{63}$. Scissors denote the S1/S2 and S2' proteolytic cleavage sites. Location of stabilizing HexaPro prolines is denoted. b,c, Spike structures in the three RBD down (PDB:6VXX) (b) and two RBD up prefusion states (PDB:6X2B) (c). Left: front view, Right: top view. HexaPro prolines shown in black. d, Composite structure of a spike monomer bound to neutralizing antibodies CR3022 (PDB: 6W41) and 4A8 (PDB:7C2L).

were solved shortly thereafter ${ }^{16,22-25}$. These structures revealed that ACE2 interacts with the receptorbinding motif, approximately composed of residues $438-508$ within the RBD ${ }^{26}$. SARS-CoV-2 receptor-binding motif has a more pronounced receptor-interacting ridge and stabilizing residues that increase the affinity for ACE2 compared with SARS-CoV- $1^{27}$. The pace of spike structures deposited in the protein data bank continues to accelerate, with multiple high-resolution structures of spike-binding antibodies and a structure of the post-fusion conformation ${ }^{18}$. We direct the reader to several reviews summarizing these structural findings ${ }^{28-31}$.

\section{Development of the protocol}

Prefusion spike is the major target for vaccine and therapeutic antibody development. However, prefusion-stabilized spike is difficult to produce recombinantly because it is a large $(\sim 141 \mathrm{kDa}$ per monomer), metastable and heavily glycosylated transmembrane protein. Nearly all structural studies of spike have thus focused on the soluble ectodomain (Fig. 1a) ${ }^{20,28,29,32-35}$. The first prefusionstabilized SARS-CoV-2 spike was informed by our structure-based engineering of the Middle East respiratory syndrome (MERS) coronavirus $S$ protein ${ }^{32}$. We showed that inserting two prolines in a loop between the first heptad repeat (HR1) and the central helix increased the homogeneity and recombinant expression yields of prefusion MERS-CoV S ectodomains ${ }^{32}$. We and others followed a 
Table 1 | Prefusion-stabilized spike trimer variants and characteristics

\begin{tabular}{|c|c|c|c|c|c|}
\hline Variant & Stabilizing mutations & Rationale & Yield & Cell line & Ref \\
\hline S-2P & K986P, V987P, furin ${ }^{a}$ & Proline & $0.5 \mathrm{mg} / \mathrm{L}$ & FreeStyle 293-F & Wrapp et al. ${ }^{19}$ \\
\hline HexaPro & $\begin{array}{l}\text { K986P, V987P, F817P, A892P, } \\
\text { A899P, A942P, furin }{ }^{a}\end{array}$ & Proline & $\begin{array}{l}10.5 \mathrm{mg} / \mathrm{L} \\
\text { (FreeStyle 293-F) } \\
32.5 \mathrm{mg} / \mathrm{L}(\text { ExpiCHO) }\end{array}$ & $\begin{array}{l}\text { FreeStyle 293-F } \\
\text { ExpiCHO }\end{array}$ & Hsieh et al. ${ }^{36}$ \\
\hline rS2d & K986P, V987P, S383C, D985C, furin ${ }^{a}$ & Disulfide & Not reported & FreeStyle 293-F & Henderson et al. ${ }^{21}$ \\
\hline u1S2q & $\begin{array}{l}\text { A570L T572I F855Y N856I (u1S2q) } \\
\text { K986P, V987P, A570L, T572I, F855Y, } \\
\text { N856I, furin }{ }^{\mathrm{a}}\end{array}$ & Cavity filling & Not reported & FreeStyle 293-F & Henderson et al. ${ }^{21}$ \\
\hline$S-R / P P / x 1$ & K986P, V987P, S383C, D985C, furin ${ }^{b}$ & Disulfide & $\sim 0.4 \mathrm{mg} / \mathrm{L}$ & Expi293F & Xiong et al. ${ }^{57}$ \\
\hline$S-R / x 2$ & K986P, G413C, V987C, furin ${ }^{b}$ & Disulfide & $\sim 0.4 \mathrm{mg} / \mathrm{L}$ & Expi293F & Xiong et al. $^{57}$ \\
\hline S-closed +Fd & $\begin{array}{l}\text { K986P, V987P, D614N, A892P, } \\
\text { A942P, V987P, furin }{ }^{a}\end{array}$ & $\begin{array}{l}\text { Cavity filling/ } \\
\text { proline }\end{array}$ & $\begin{array}{l}\text { Sixfold increased } \\
\text { relative to } S-2 P\end{array}$ & Expi293F & Juraszek et al. ${ }^{53}$ \\
\hline 2P DS S & K986P, V987P, S383C/D985C, furin ${ }^{c}$ & Disulfide & $\begin{array}{l}\text { Tenfold reduced } \\
\text { relative to } S-2 P\end{array}$ & FreeStyle 293-F & McCallum et al. ${ }^{56}$ \\
\hline N234A & K986P, V987P, N234A & Glycan deletion & $2.0 \mathrm{mg} / \mathrm{L}$ & FreeStyle 293-F & Henderson et al. ${ }^{58}$ \\
\hline VFLIP & $\begin{array}{l}\text { F817P, A892P, A899P, A942P, } \\
\text { K986P, Y707C, T883C, K986, furin }\end{array}$ & $\begin{array}{l}\text { Proline, } \\
\text { disulfide, linker }\end{array}$ & $\begin{array}{l}7.1 \mathrm{mg} / \mathrm{L}(\mathrm{HEK} 293 \mathrm{~F}) \\
157 \mathrm{mg} / \mathrm{L}(\text { ExpiCHO) }\end{array}$ & $\begin{array}{l}\text { HEK293F } \\
\text { ExpiCHO }\end{array}$ & Olmedillas et al. $^{73}$ \\
\hline
\end{tabular}

${ }^{a} \mathrm{~S} 1 / \mathrm{S} 2$ furin cleavage site $\left({ }_{682} \mathrm{RRAR}_{685}\right)$ mutated to ${ }_{682} \mathrm{GSAS}_{685}{ }^{\mathrm{b}} \mathrm{S} 1 / \mathrm{S} 2$ furin cleavage site mutated to ${ }_{681} \mathrm{PRRAR}_{685}{ }^{\mathrm{c}} \mathrm{S} 1 / \mathrm{S} 2$ furin cleavage site mutated to ${ }_{682} \mathrm{SGAG}{ }_{685}$. ${ }^{\mathrm{d}} \mathrm{S} 1 / \mathrm{S} 2$ furin cleavage site mutated to ${ }_{675}$ GGSGGGS $_{691}$.

similar strategy to insert two prolines into the SARS-CoV-2 ectodomain, termed S-2P (Table 1$)^{19,20}$. However, S-2P yield continued to be relatively poor ${ }^{19}$. Thus, we developed a second-generation prefusion-stabilized SARS-CoV-2 ectodomain by introducing four additional prolines, termed HexaPro (Addgene, 154754), that further stabilized the trimeric spike structure in the prefusion conformation and increased recombinant protein yield by an additional tenfold above spike- $2 \mathrm{P}^{36}$. Despite the increased stability of HexaPro, the RBDs continue to sample multiple positions ${ }^{36,37}$.

Here, we describe the expression, purification and biophysical characterization of HexaPro, a second-generation prefusion-stabilized SARS-CoV-2 spike glycoprotein from mammalian cells ${ }^{36}$. In addition to developing HexaPro, we have used this protocol to rapidly screen circulating spike mutants, to develop new spike antigens, and for structure-function studies of spike conformations ${ }^{37-40}$. We also describe three widely available assays to characterize recombinant spikes: (1) spike thermostability; (2) affinity for ACE2; and (3) binding by patient sera or monoclonal antibodies. Although beyond the scope of this paper, we also recommend visualizing recombinant spikes via negative-stain electron microscopy to check for monodispersity and the overall distribution of conformations. We anticipate that this protocol will be useful for research groups that need to express and purify spike variants and broadly applicable to studies of other trimeric viral fusion proteins.

\section{Applications of the method}

Structure-function studies of recombinant SARS-CoV-2 spike protein alone and in complex with ACE2 are critical for understanding how the virus infects human cells ${ }^{2,3}$. Prefusion spike is in a metastable state that undergoes conformational 'breathing' of the RBDs ${ }^{19,37}$. This allows the three RBDs to adopt an open conformation that can interact with the ACE2 cell surface receptors to trigger the post-fusion conformation and viral entry. Binding affinity studies with recombinant SARS-CoV-2 spike showed a higher affinity than SARS-CoV-1 for human ACE2 ${ }^{19,34}$. This interaction is unaffected by the glycan shield near the $\mathrm{RBD}^{41}$.

Recombinant SARS-CoV-2 spike is essential for probing the immune response of convalescent patients and developing monoclonal antibody $(\mathrm{mAb})$ therapeutics. For example, enzyme-linked immunosorbent assays (ELISAs) can detect seroconverted individuals ${ }^{42}$. While the soluble RBD can be used for some assays ${ }^{43,44}$, full-length spike is essential for characterizing antibodies that bind outside the RBD, including the N-terminal domain $\left(\mathrm{NTD}^{45,46}\right)$ and the $\mathrm{S} 2 \mathrm{stalk}^{47,48}$. Targeting these regions of the protein is especially important because they provide alternative neutralizing epitopes 
for antibody therapeutics ${ }^{40,49,50}$. In addition, serological assays with recombinant spike can measure patient immune response and neutralizing convalescent plasma.

Prefusion spike is a critical antigenic target for eliciting neutralizing antibodies in leading SARS-CoV-2 vaccine candidates ${ }^{51,52}$. Recombinant production of wild-type MERS and SARS-CoV-1 spikes included a heterogeneous mixture of both pre- and post-fusion conformations ${ }^{32}$. Class I fusion proteins are inherently unstable, and the SARS-CoV-2 spike dissociates into the S1 and S2 subdomains. Immunization with constructs that adopt post-fusion conformations reduces specific S1 neutralizing or ACE2 blocking antibodies ${ }^{53}$. Therefore, leading SARS-CoV-2 subunit vaccines, including those from Pfizer, Moderna and NovaVax, are using prefusion-stabilized spikes ${ }^{51,52,54,55}$. These stabilized constructs display the spike proteins in a trimeric, prefusion conformation with the same glycosylated residues as in the wild-type virus (but possibly different glycan linkages) ${ }^{20,55}$. Additionally, the stabilized constructs may increase the functional protein yield and further increase vaccine response. Thus, multiple vaccine candidates use stabilized, full-length spike glycoprotein to elicit an immune response.

\section{Comparison with other methods}

Although HexaPro is highly stable with increased yield, the following complementary approaches have been reported to stabilize prefusion coronavirus spike proteins: (1) stabilizing the hinge loop undergoing conformational change to extended helix ${ }^{32} ;(2)$ adding disulfide bonds to prevent conformational changes during the pre- to post-fusion states ${ }^{21}$; (3) introducing salt bridges to neutralize charge imbalances ${ }^{36}$; (4) point-mutating to hydrophobic residues to fill internal cavities ${ }^{21,53}$; and (5) changing the surface glycosylation pattern ${ }^{21}$. Table 1 summarizes these approaches applied to the SARS-CoV-2 spike and the reported yields per liter of cell culture. One approach locks the RBD in a closed state via an engineered intermolecular disulfide bond between an RBD residue (S383C) and the hairpin preceding the S2 central helix (D985C) from a neighboring protomer ${ }^{21,56,57}$. The cryo-electron microscopy (cryo-EM) structure of this variant (rS2d and S-R/PP/x1, Table 1) confirmed that spike is covalently trapped in an all-down conformation ${ }^{21}$. Conformations favoring the three RBD-down state may limit exposure of cryptic epitopes for antibody neutralization. A single mutation of an N-glycan site (N234A) reduces the population of up-RBD spikes ${ }^{58}$. This change is attributed to additional occupancy of the cleft formed by the NTD and RBD. Another spike variant increased overall yield five- to sixfold by adding one cavity-filling mutation and five proline substitutions $^{53}$. Finally, engineering spikes also abolish the furin cleavage site. Furin cleavage between S1 and S2 is pivotal for SARS-CoV-2 pathogenesis ${ }^{12}$. Mutating the furin cleavage site prevents separation of the S1 and S2 domains and stabilizes the full-length prefusion ectodomain ${ }^{15}$.

\section{Limitations}

The differences between HexaPro and other stabilized spike constructs may be especially notable in the context of eliciting neutralizing antibodies, as the precise contribution of conformations to stimulating our immune response is unclear. HexaPro, additionally, removes the furin cleavage at the S1/S2 interface. This is crucial for the downstream utilization of stabilized spikes, such as viral uptake assays. The presence of the furin cleavage site is additionally critical for understanding the viral transmissibility in clinical variants such as D614G, where increased furin site accessibility and cleavage may be responsible for increase infectivity ${ }^{59}$. ELISAs utilizing the HexaPro stabilized trimer showed increased sensitivity for seroconversion compared with individual spike subunits ${ }^{60}$. Additionally, HexaPro does not transition into the post-fusion conformation, eliminating any newly exposed post-fusion antigenic sites ${ }^{18}$. Nonetheless, we anticipate that some epitopes may be obscured by prefusion-stabilized HexaPro.

SARS-CoV-2 spike is highly glycosylated with 22 predicted N-linked glycosylated sites and five predicted O-linked glycosylated sites ${ }^{20,61,62}$. Several cryo-EM structures and mass spectrometry analyses of recombinant spike purified from FreeStyle 293-F cells (HEK293 derivative) confirmed 22 $\mathrm{N}$-linked glycosylated sites, strong occupation of O-linked glycosylation at Thr323, and trace levels of O-linked glycosylation at Thr325 $5^{20,62,63}$. Recombinant spike has $89 \%$ complex-type and $11 \%$ oligomannose/hybrid N-glycans, whereas virus-derived spike has a slight difference, with $79 \%$ complextype and $21 \%$ oligomannose/hybrid $\mathrm{N}$-glycans ${ }^{64}$. Despite minimal large-scale $\mathrm{N}$-glycan change, specific N-glycan sites (for example, Asn61, Asn234 and Asn603) are predominantly underprocessed oligomannose in virus-derived spike. In contrast, Asn234 was mixed complex and oligomannose/ hybrid N-glycans, while Asn61 and Asn603 was mostly complex N-glycans in recombinant spike. 


\begin{tabular}{|c|c|c|c|}
\hline \multicolumn{2}{|l|}{ Days $0-5$} & Day 6 & ays $6+$ \\
\hline \multicolumn{2}{|c|}{ Cell culture and spike expression } & Purification & Characterization \\
\hline A. FreeStyle 293-F & B. ExpiCHO-S & & \\
\hline $\begin{array}{l}\text { Cell seeding } \\
\text { (substeps i-ii) }\end{array}$ & $\begin{array}{c}\text { Cell seeding } \\
\text { (substeps i-ii) }\end{array}$ & $\begin{array}{l}\text { Affinity resin } \\
\text { (step 2) }\end{array}$ & $\begin{array}{l}\text { Thermostability } \\
\text { (steps 7-11) }\end{array}$ \\
\hline $\begin{array}{l}\text { Cell transfection } \\
\text { (substeps iii-viii) }\end{array}$ & $\begin{array}{l}\text { Cell transfection } \\
\text { (substeps iii-x) }\end{array}$ & Size exclusion & $\begin{array}{c}\text { BLI } \\
\text { (steps 12-20) }\end{array}$ \\
\hline $\begin{array}{l}\text { Cell collection } \\
\text { (substeps ix-xiii) }\end{array}$ & $\begin{array}{l}\text { Cell collection } \\
\text { (substeps xi-xx) }\end{array}$ & (steps 3-6) & $\begin{array}{c}\text { ELISA } \\
\text { (steps 21-37) }\end{array}$ \\
\hline
\end{tabular}
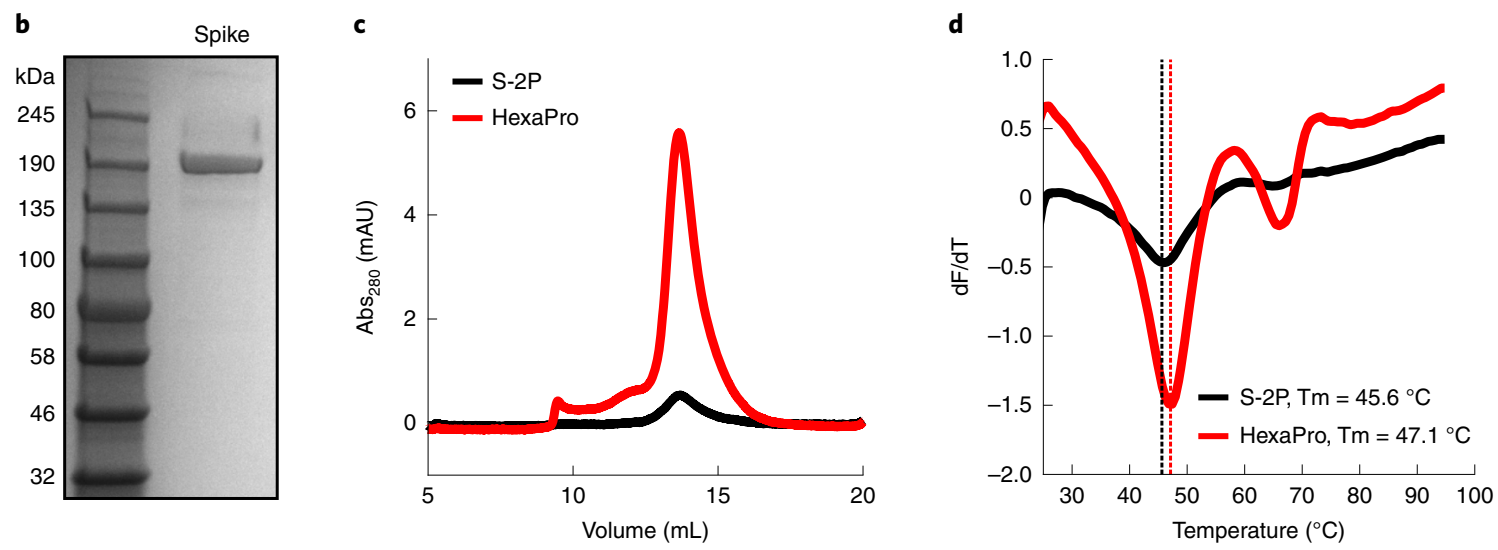

e

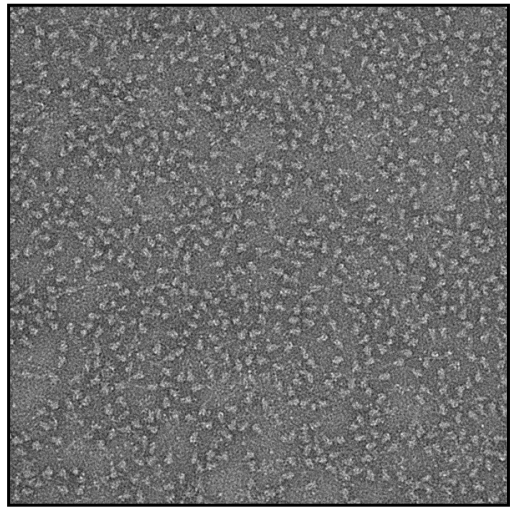

f

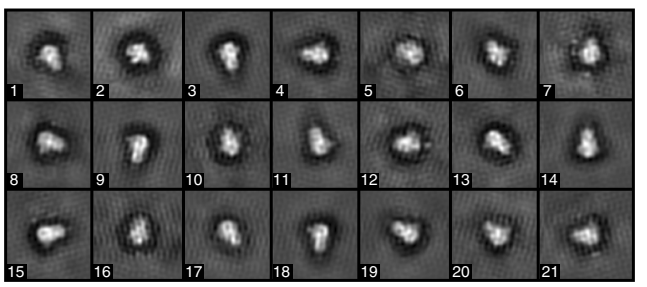

Fig. 2 | Purification and characterization of the SARS-CoV-2 spike. a, Overview and timeline of the protocol. b, SDS-PAGE gel of recombinant spike after elution from the Strep-Tactin column. c, Superose- 6 traces of S-2P and HexaPro. Note the higher yield for HexaPro. d, Differential scanning fluorimetry analysis. e, A negative-stain electron micrograph. f, 2D class averages of HexaPro.

Moreover, Thr678 modifications identified on the virus-derived spike are absent on recombinant spike. Interestingly, multiple $\mathrm{N}$-linked glycosylations and Thr323/Thr325 O-linked glycosylations are located on the $\mathrm{RBD}^{64}$. The glycosylation patterns of recombinant spike purified from $\mathrm{CHO}$ cells are unexplored ${ }^{65,66}$. The functional differences in glycosylation patterns between HEK293- or CHO-purified spike are unknown ${ }^{62,63}$ but should be considered when interpreting differences between binding affinities for ACE2 or mAbs across different constructs.

\section{Experimental design}

This protocol consists of three main segments (Fig. 2a): cell culture and spike expression (Step 1); spike purification (Steps 2-6); and spike characterization (Steps 7-37). Mammalian cell lines are cultured in a biosafety level 2 or greater laboratory. Maintaining an aseptic environment to avoid contamination is essential because the mammalian cell cultures are not supplemented with antibiotics in this protocol. Institutional guidelines should be followed for handling all biohazards associated with tissue culture and proteins derived from human pathogens. 
We present two laboratory-scale protocols for purifying HexaPro from FreeStyle 293-F and ExpiCHO-S cells. The choice of protocol and cell line will depend on the quantity of spike protein and its glycosylation pattern. Smaller-scale expression is useful for producing up to $\sim 0.5 \mathrm{mg}$ of spike in FreeStyle 293-F cells or $>1 \mathrm{mg}$ in ExpiCHO-S cells for screening spike variants. Expression of up to $\sim 10$ $\mathrm{mg} / \mathrm{L}$ in FreeStyle 293-F cells or $\sim 30 \mathrm{mg} / \mathrm{L}$ in ExpiCHO-S cells is useful for serology, structural biology and other protein-intensive applications. Both cell lines produce trimeric HexaPro spikes with similar affinities for ACE $2^{36}$. Notably, the glycosylation pattern will differ between the two cell lines. Our early publications included kifunensine ${ }^{67}$, an endoplasmic reticulum mannosidase I inhibitor, which aids in some structural biology studies but may result in unnaturally large glycosylation chains. Kifunensine prevents the removal of mannose residues from glycoproteins resulting in large mannose-based glycans ${ }^{68}$. Recent glycomapping studies concluded that viral SARS-CoV-2 spike also contains complex glycans but this pattern is unlikely to match those generated with kifunensine ${ }^{10,63}$. Adding kifunensine does not impact spike expression or ACE2-spike affinity but may alter antibody binding. For these reasons, and because this is an expensive reagent, we have shifted away from supplementing our cultures with this inhibitor. If a researcher chooses to use kifunensine, it should be added at a final concentration of $5 \mu \mathrm{M}$ at Step $1 \mathrm{~A}$ (viii) of the FreeStyle 293-F protocol. For large-scale HexaPro production, we recommend using ExpiCHO cells and omitting kifunensine to reduce the overall costs.

HexaPro ectodomain is expressed with a C-terminal foldon domain with HRV 3C cleavage site and a tandem His ${ }_{8}$-TwinStrep ( $2 \times$ Strep-tag II) epitope. Removing either affinity epitope does not change spike yield or overall purification quality. Purification with Ni-NTA resin is more cost effective, and yields $>90 \%$ pure spike protein as assayed by SDS-PAGE. Strep-Tactin-purified spike is slightly purer ( $>95 \%$ pure) and our preferred purification choice for smaller-scale expression. We purify HexaPro via a single-step affinity column at room temperature, followed by size exclusion chromatography at $4{ }^{\circ} \mathrm{C}$. Post-purification, recombinantly produced spikes are stored on ice for immediate experiments or flash frozen in liquid nitrogen and stored at $-80^{\circ} \mathrm{C}$. Although HexaPro is exceptionally stable at elevated temperatures, other spike constructs are sensitive to the purification temperature ${ }^{69}$.

The entire procedure for purifying spike takes 1-2 weeks depending on the cell lines used (Fig. 2a). This includes the following stages: cell culture and transfection (Step 1), spike purification (Steps 2-6) and biochemical characterization (Steps 7-37, depending on the final goal). Finally, although we focus on the expression, purification and biophysical analysis of the prefusion-stabilized HexaPro variant, we expect that the procedure described herein is broadly applicable for the purification of other prefusion-stabilized or clinically relevant spike variants.

Materials

\section{Reagents}

Cell culture

- HexaPro expression vector (Addgene, cat. no. 154754)

- FreeStyle 293-F cells (Gibco, cat. no. R79007)

- FreeStyle 293 expression medium (Gibco, cat. no. 12338026)

- Opti-MEM I reduced serum medium (Gibco, cat. no. 31985070)

- Polyethylenimine (PEI), linear, MW 25000, transfection grade (Polysciences, cat. no. 23966-1)

- Sodium hydroxide (NaOH; EMD Millipore, cat. no. SX0590) ! CAUTION NaOH is a harmful irritant.

Wear protective clothing and equipment.

- ExpiCHO-S cells (Gibco, cat. no. A29127)

- ExpiCHO expression medium (Gibco, cat. no. A2910001)

- ExpiFectamine CHO transfection kit (Gibco, cat. no. A29129)

- ExpiFectamine CHO reagent

- ExpiFectamine $\mathrm{CHO}$ enhancer

- ExpiCHO feed

- OptiPRO SFM complexation medium (Gibco, cat. no. 12309050)

- Kifunensine (optional, GlycoFineChem, cat. no. 109944-15-2)

- Trypan blue solution (Gibco, cat. no. 15250061)

\section{Spike purification}

- Tris base (Research Products International, cat. no. T60040)

- Hydrochloric acid (HCl; Fisher Scientific, cat. no. A144) ! CAUTION $\mathrm{HCl}$ is a harmful irritant. Wear protective equipment. 
- Sodium chloride (VWR, cat. no. BDH9286)

- Ethylenediaminetetraacetic acid (EDTA; Fisher Scientific, cat. no. S312) ! CAUTION EDTA is a harmful irritant. Wear protective equipment.

- Sodium azide (Fisher Scientific, cat. no. S2271) ! CAUTION Sodium azide is toxic. Wear protective equipment.

- Imidazole (Sigma-Aldrich, cat. no. 792527)

- D-desthiobiotin (Sigma-Aldrich, cat. no. D1411)

-2× Laemmli sample buffer (Biorad, cat. no. 1610737)

-2-mercaptoethanol (Fisher Scientific, cat. no. BP176) ! CAUTION 2-mercaptoethanol is a harmful irritant. Wear protective equipment.

\section{Thermostability assay}

- SYPRO orange protein gel stain (Thermo Fisher Scientific, cat. no. S6650)

- MicroAmp Fast Optical 96-Well Reaction Plate, $0.1 \mathrm{~mL}$ (Thermo Fisher Scientific, cat. no. 4346970)

\section{Bio-layer interferometry}

- HBS-EP+ Buffer 10× (Cytiva, cat. no. BR100669)

- Bovine serum albumin (New England Biolabs, cat. no. B9000S)

\section{Enzyme-linked immunosorbent assay}

- Phosphate-buffered saline (PBS; Thermo Fisher Scientific, cat. no. 10010023)

- Tween 20 (Sigma-Aldrich, cat. no. P9416)

- Nonfat dry milk (Sigma-Aldrich, cat. no. M7409)

- Anti-spike antibodies, such as mAb CR3022 (Abcam, cat. no. ab273073)

- Anti-human IgG Fab horseradish peroxidase (HRP) (Sigma-Aldrich, cat. no. A0293)

- 1-Step Ultra TMB ELISA substrate (Thermo Fisher Scientific, cat. no. 34028)

- Sulfuric acid ( $\mathrm{H}_{2} \mathrm{SO}_{4}$; Fisher Scientific, cat. no. 7664-93-9) ! CAUTION $\mathrm{H}_{2} \mathrm{SO}_{4}$ is a harmful irritant. Wear protective equipment.

\section{Equipment}

Cell culture

- Celltron benchtop shaker for $\mathrm{CO}_{2}$ incubators, $25 \mathrm{~mm}$ (Infors-HT, cat. no. I69222)

- LUNA-II automated cell counter (Logos Biosystems, cat. no. L40002)

- LUNA cell counting slides (Logos Biosystems, cat. no. L12001)

- CellXpert $\mathrm{C} 170 \mathrm{CO}_{2}$ incubator (Eppendorf, cat. no. 6734010015)

- $\mathrm{CO}_{2}$ gas

- Laminar flow tissue culture hood

- Water bath, $37{ }^{\circ} \mathrm{C}$ (Thermo Fisher Scientific, cat. no. TSGP05)

- Nalgene; single-use polyethylene terephthalate (PETG) Erlenmeyer flasks with plain bottom: sterile (Thermo Fisher Scientific, cat. no. 4115-0125)

- Nalgene; single-use PETG Erlenmeyer flasks with plain bottom: sterile (Thermo Fisher Scientific, cat. no. 4115-0500)

- Nalgene; single-use PETG Erlenmeyer flasks with plain bottom: sterile (Thermo Fisher Scientific, cat. no. 4115-2800)

- $0.22 \mu \mathrm{m}$ syringe tip filter (Genesee Scientific, cat. no. 25-244)

- Plastic syringes $10 \mathrm{~mL}$ and $60 \mathrm{~mL}$ (BD, cat. nos. 302995 and 309653)

- Centrifuge tube, $250 \mathrm{~mL}$ (Corning, cat. no. 430776)

\section{Protein purification}

- $\mathrm{pH}$ probe (Fisher Scientific, cat. no. 01-913-996)

- Water filtration source (Millipore Sigma)

- Superose 6 Increase 10/300 GL (GE Healthcare, cat. no. 29091596)

- SDS-PAGE gels, 4-15\% (Biorad, cat. no. 4561084)

- Electrophoresis equipment, MiniPROTEAN Tetra Cell (Biorad, cat. no. 1658001EDU)

- Electrophoresis power supply (Biorad, cat. no. 1645050EDU)

- Color pre-stained protein standard, broad range (NEB, cat. no. P7712S)

- Electrophoresis gel stain (VWR, cat. no. 82021)

- 10× Buffer R; Strep-Tactin regeneration buffer with HABA (IBA, cat. no. 2-1002) 
- Strep-Tactin Superflow 50\% suspension (IBA, cat. no. 2-1206)

- Ni-NTA (Thermo Fisher Scientific, cat. no. 88222)

- Microtubes, $1.7 \mathrm{~mL}$ (Genesee Scientific, cat. no. 22-282)

- Microtubes, $1.7 \mathrm{~mL}$ capless (Genesee Scientific, cat. no. 24-282NC)

- Centrifuge tube, $50 \mathrm{~mL}$ (Spectrum Chemical, cat. no. 972-95667)

- Centrifuge tube, 15 mL (Spectrum Chemical, cat. no. 972-95652)

- Poly-Prep columns (Bio-Rad, cat. no. 7311550)

- Amicon Ultra-15 centrifugal filter unit, $30 \mathrm{kDa}$ cutoff (Millipore Sigma, cat. no. UFC9030)

- Centrifuge for $50 \mathrm{~mL}$ conical tubes (Beckman Coulter, Avanti J-26 XP)

- Microcentrifuge for $1.7 \mathrm{~mL}$ tubes, refrigerated (Eppendorf, Centrifuge $5427 \mathrm{R}$ )

- Fast protein liquid chromatograph, with fraction collector (GE Healthcare, AKTA Pure 25)

- Scale, mg sensitivity (Fisher Scientific, cat. no. 01-910-200)

\section{Bio-layer interferometry}

- Label-free bio-layer interferometry (BLI) detection system (Octet RED96e System, ForteBio)

- Streptavidin (SA) biosensors (ForteBio, cat. no. 18-5019)

ELISA

- Corning Costar 96-well assay plate (Fisher Scientific, cat. no. 3361).

- Orbital plate shaker (VWR, cat. no. 10027-120)

- Plate reader (BioTek; Synergy HTX Multi-Mode Reader)

\section{Reagent setup}

PEI (1 mg/mL stock)

Dissolve $1 \mathrm{~g}$ of PEI $25 \mathrm{~K}$ into $900 \mathrm{~mL}$ of $\mathrm{ddH}_{2} \mathrm{O}$, and titrate to $\mathrm{pH}<2.0$ with $\mathrm{HCl}$. After $3 \mathrm{~h}$, titrate to $\mathrm{pH}$ 7.0 with $\mathrm{NaOH}$. Add $\mathrm{ddH}_{2} \mathrm{O}$ to $1 \mathrm{~L}$. Sterilize through a $0.22 \mu \mathrm{m}$ filter. Store at $-20{ }^{\circ} \mathrm{C}$ for up to 1 year.

\section{Kifunensine (optional, $5 \mathrm{mM}$ stock)}

Dissolve $250 \mathrm{mg}$ of kifunensine in $227 \mathrm{~mL}$ of $\mathrm{ddH}_{2} \mathrm{O}$ while mixing at RT overnight. Sterilize through a $0.22 \mu \mathrm{m}$ filter. Store at $-20{ }^{\circ} \mathrm{C}$ for up to 1 year.

FreeStyle 293 expression medium

No supplementation is required. Antibiotics are not recommended.

\section{ExpiCHO expression medium}

No supplementation is required. Antibiotics are not recommended.

\section{Growth and maintenance of suspension FreeStyle 293-F cells}

Incubate suspension cell cultures in a $37^{\circ} \mathrm{C}$ incubator containing a humidified atmosphere of $8 \% \mathrm{CO}_{2}$ and rotating continuously at 120-130 rpm for small cultures and $80-90 \mathrm{rpm}$ for large cultures. Subculture cells when the density is $\sim 2-3 \times 10^{6}$ cells $/ \mathrm{mL}$. Dilute cells to $2-3 \times 10^{5}$ viable cells $/ \mathrm{mL}$ in fresh and prewarmed $\left(37^{\circ} \mathrm{C}\right)$ FreeStyle 293 expression medium. Subculture cells every $3-4 \mathrm{~d}$ using a new single-use PETG Erlenmeyer flask (sterile).

\section{Growth and maintenance of suspension ExpiCHO-S cells}

Incubate suspension cell cultures as for FreeStyle 293-F cells. Subculture cells when the density is $\sim 4-6 \times 10^{6}$ cells $/ \mathrm{mL}$. Dilute cells to $2-3 \times 10^{5}$ viable cells $/ \mathrm{mL}$ in fresh and prewarmed $\left(37^{\circ} \mathrm{C}\right)$ ExpiCHO expression medium. Subculture cells every 3-4 d using a new single-use PETG Erlenmeyer flask (sterile).

\section{Strep-Tactin wash buffer}

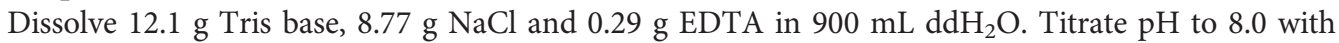
$\mathrm{HCl}$. Add $\mathrm{ddH}_{2} \mathrm{O}$ to $1 \mathrm{~L}$. Sterilize through a $0.22 \mu \mathrm{m}$ filter. Store at $4{ }^{\circ} \mathrm{C}$ for up to $1 \mathrm{month}$.

\section{Strep-Tactin elution buffer}

Take $50 \mathrm{~mL}$ Strep-Tactin wash buffer and add $28 \mathrm{mg}$ of $\mathrm{D}$-desthiobiotin ( $2.5 \mathrm{mM}$ final concentration). Vortex to mix. Store at $4{ }^{\circ} \mathrm{C}$ for up to 1 month. 


\section{Ni-NTA wash buffer}

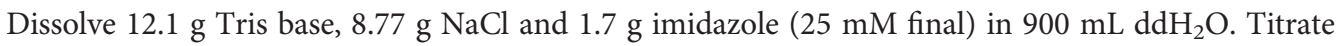
$\mathrm{pH}$ to 8.0 with $\mathrm{HCl}$. Add $\mathrm{ddH}_{2} \mathrm{O}$ to $1 \mathrm{~L}$. Sterilize through a $0.22 \mu \mathrm{m}$ filter. Store at $4{ }^{\circ} \mathrm{C}$ for up to 1 month. Protect imidazole from excess light.

\section{Ni-NTA elution buffer}

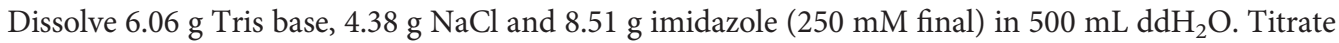
$\mathrm{pH}$ to 8.0 with $\mathrm{HCl}$. Add $\mathrm{ddH}_{2} \mathrm{O}$ to $500 \mathrm{~mL}$. Sterilize through a $0.22 \mu \mathrm{m}$ filter. Store at $4{ }^{\circ} \mathrm{C}$ for up to 1 month. Protect imidazole from excess light.

\section{Superose 6 SEC buffer}

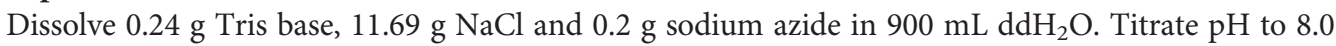
with $\mathrm{HCl}$. Add $\mathrm{ddH}_{2} \mathrm{O}$ to $1 \mathrm{~L}$. Sterilize through a $0.22 \mu \mathrm{m}$ filter. Store at $4{ }^{\circ} \mathrm{C}$ for up to 1 month.

\section{$2 \times$ Laemmli sample buffer preparation}

Mix $950 \mu \mathrm{L} 2 \times$ Laemmli sample buffer and $50 \mu \mathrm{L} 2$-mercaptoethanol. Vortex to mix. Store at RT indefinitely.

PBST (0.1\%)

Mix $100 \mathrm{~mL}$ of PBS pH 7.5 with $100 \mu \mathrm{L}$ of Tween 20 . Sterilize through a $0.22 \mu \mathrm{m}$ filter. Store at $4{ }^{\circ} \mathrm{C}$ for up to 1 month.

\section{PBSTM (1\%)}

Mix $100 \mathrm{~mL}$ of PBS pH 7.5 with $50 \mu \mathrm{L}$ of Tween 20 and $1 \mathrm{~g}$ of nonfat dried milk. Sterilize through a $0.22 \mu \mathrm{m}$ filter. Store at $4{ }^{\circ} \mathrm{C}$ for up to 1 week.

\section{BLI buffer}

Dilute $5 \mathrm{~mL}$ of $10 \times$ HBS-EP+ buffer to $50 \mathrm{~mL}$. Vortex to mix. Store at RT for up to 1 week.

\section{Procedure}

\section{Cell culture and spike expression Timing 6-14 d}

1 Express SARS-CoV-2 spike in either FreeStyle 293-F (option A) or ExpiCHO-S (option B) cells. ! CAUTION Cell cultures are a potential biohazard. Ensure that mammalian cell work is performed in an approved laminar flow hood using aseptic technique. Follow institutional and governmental guidelines for recommended personal protective equipment and waste disposal while working with cell cultures.

\section{? TROUBLESHOOTING}

(A) Expression in FreeStyle 293-F cells Timing 6 d

(i) Cell seeding. For small-scale expression, dilute cells to $\sim 5 \times 10^{5}$ cells $/ \mathrm{mL}$ in a $125 \mathrm{~mL}$ singleuse PETG Erlenmeyer flask to a total volume of $36 \mathrm{~mL}\left(\sim 1.8 \times 10^{7}\right.$ cells $)$ with fresh, prewarmed FreeStyle 293 expression medium. Alternatively, for large-scale expression, dilute cells to $\sim 5 \times 10^{5} \mathrm{cell} / \mathrm{mL}$ in a $2,800 \mathrm{~mL}$ single-use PETG Erlenmeyer flask to a total volume of $900 \mathrm{~mL}\left(\sim 4.5 \times 10^{8}\right.$ cells $)$ with fresh, prewarmed FreeStyle 293 expression medium.

$\triangle$ CRITICAL STEP All cell culture solutions and equipment must be sterile. Culture suspension should not exceed $30-40 \%$ of the total flask volume. Ensure that cell viability is always $>95 \%$.

(ii) Incubate cultures at $37{ }^{\circ} \mathrm{C}$ with $8 \% \mathrm{CO}_{2}$, shaking $(120-130 \mathrm{rpm}$ for small scale or 80-90 rpm for large scale) for 16-20 h.

(iii) Cell transfection. Mix $20 \mu \mathrm{L}$ of seeded culture with $20 \mu \mathrm{L}$ of trypan blue solution (1:1 ratio), and assess viability and density on a cell counting slide. Ensure that cell density is $\sim 1.0-1.2 \times$ $10^{6}$ cells $/ \mathrm{mL}$ and cell viability is $>95 \%$ for optimal transfection efficiency. ? TROUBLESHOOTING

(iv) For small-scale experiments, add $2 \mathrm{~mL}$ of room temperature (RT, $25^{\circ} \mathrm{C}$ ) OptiMEM to a labeled $15 \mathrm{~mL}$ conical tube for each transfection, add $25 \mu \mathrm{g}$ of plasmid DNA to each tube and mix by vortexing. For large-scale experiments, add $50 \mathrm{~mL}$ of RT OptiMEM to a labeled $50 \mathrm{~mL}$ conical tube for each transfection, add $1 \mathrm{mg}$ of plasmid DNA to each tube and mix by vortexing. 
(v) Create a transfection mix by adding $3 \mu \mathrm{L}$ PEI per $1 \mu \mathrm{g}$ plasmid DNA and OptiMEM (2 mL in a $15 \mathrm{~mL}$ conical tube per small-scale transfection or $50 \mathrm{~mL}$ in a $250 \mathrm{~mL}$ conical tube per large-scale transfection) for each transfection. Mix by vortexing.

(vi) Filter the OptiMEM/plasmid DNA mix (2 mL for small scale or $50 \mathrm{~mL}$ for large scale) through a $0.22 \mu \mathrm{m}$ syringe filter into the conical tube containing an equal volume of transfection mix. Mix by inversion.

(vii) Wait $20 \mathrm{~min}$ and slowly add each final transfection mix (4 mL for small scale or $100 \mathrm{~mL}$ for large scale) to the cell cultures.

(viii) Incubate cultures at $37{ }^{\circ} \mathrm{C}$ with $8 \% \mathrm{CO}_{2}$, shaking until time for collection. $\triangle$ CRITICAL STEP Ensure that the plasmid DNA is endotoxin free and concentrated to $>500 \mathrm{ng} / \mu \mathrm{L}$. Do not syringe filter the transfection master mix or the final transfection mix after the DNA and PEI have been added. This will reduce the transfection efficiency.

(ix) Cell collection. Pour cultures into $50 \mathrm{~mL}$ (small scale) or $250 \mathrm{~mL}$ (large scale) conical tubes.

(x) Centrifuge at $500 \mathrm{~g}$ for $10 \mathrm{~min}$ at $4{ }^{\circ} \mathrm{C}$ to separate cells from the supernatant.

(xi) Transfer the supernatant to fresh tubes without disturbing the cell pellet.

(xii) Centrifuge supernatants at $10,000 \mathrm{~g}$ for $20 \mathrm{~min}$ at $4{ }^{\circ} \mathrm{C}$ to separate debris from the supernatant. Transfer purified supernatant to fresh conical tubes without disturbing the pellet.

(xiii) Keep supernatant at $4{ }^{\circ} \mathrm{C}$ for same-day protein purification.

PAUSE POINT Store supernatants at $-80^{\circ} \mathrm{C}$ for later purification. We did not observe any changes in purified spike quality between supernatants that were frozen at $-80{ }^{\circ} \mathrm{C}$ and those that were used immediately.

(B) Expression in ExpiCHO-S Cells Timing $14 \mathrm{~d}$

(i) Cell seeding. For small-scale expression, dilute cells to $\sim 4 \times 10^{6}$ cells $/ \mathrm{mL}$ in a $125 \mathrm{~mL}$ single-use PETG Erlenmeyer flask to a total volume of $25 \mathrm{~mL}\left(\sim 1 \times 10^{8}\right.$ cells $)$ with fresh, prewarmed ExpiCHO expression medium. For large-scale expression, dilute cells to $\sim 4 \times 10^{6}$ cells $/ \mathrm{mL}$ in a $2,800 \mathrm{~mL}$ single-use PETG Erlenmeyer flask to a total volume of $750 \mathrm{~mL}\left(\sim 3 \times 10^{9}\right.$ cells $)$ with fresh, prewarmed ExpiCHO expression medium.

$\triangle$ CRITICAL STEP Ensure that cell viability is always $>95 \%$ prior to transfections. Avoid vortexing cells.

? TROUBLESHOOTING

(ii) Incubate cultures at $37{ }^{\circ} \mathrm{C}$ with $8 \% \mathrm{CO}_{2}$, shaking $(120-130 \mathrm{rpm}$ for small scale or 80-90 rpm for large scale) for 16-20 h.

(iii) Cell transfection. Mix $20 \mu \mathrm{L}$ of seeded culture with $20 \mu \mathrm{L}$ of trypan blue solution (1:1 ratio), and assess viability and density on a cell counting slide. Ensure that cell density is $\sim 7-10 \times$ $10^{6}$ cells $/ \mathrm{mL}$ and cell viability is $>95 \%$ for optimal transfection efficiency. Dilute cultures to $6 \times 10^{6}$ cells $/ \mathrm{mL}$ by discarding excess cells and diluting with fresh, prewarmed ExpiCHO expression medium back to the original culture volume.

(iv) Chill the ExpiFectamine $\mathrm{CHO}$ reagent and plasmid DNA to $4{ }^{\circ} \mathrm{C}$.

(v) For small-scale experiments, add $1 \mathrm{~mL}$ of OptiPRO medium and $20 \mu \mathrm{g}$ of plasmid DNA to a $1.5 \mathrm{~mL}$ tube for each transfection and mix by inversion. For large-scale experiments, add $30 \mathrm{~mL}$ of OptiPRO medium and $600 \mu \mathrm{g}$ of plasmid DNA to a $50 \mathrm{~mL}$ conical tube for each transfection and mix by inversion.

(vi) Invert the ExpiFectamine $\mathrm{CHO}$ reagent several times prior to use.

(vii) For small-scale experiments, add $80 \mu \mathrm{L}$ of ExpiFectamine $\mathrm{CHO}$ reagent to $920 \mu \mathrm{L}$ of OptiPRO medium in a $1.5 \mathrm{~mL}$ tube and mix by inversion. For large-scale experiments, add $2.4 \mathrm{~mL}$ of ExpiFectamine $\mathrm{CHO}$ reagent to $28 \mathrm{~mL}$ of OptiPRO medium in a fresh $250 \mathrm{~mL}$ conical tube and mix by inversion.

(viii) Add the diluted plasmid DNA from step (v) to the ExpiFectamine CHO solution from step (vii), and mix by inversion.

(ix) Incubate ExpiFectamine $\mathrm{CHO} /$ plasmid DNA complex at RT for $5 \mathrm{~min}$. Then, slowly add the solution to the diluted cell culture from step (iii), swirling the flask gently during the addition.

(x) Incubate the flask in a humidified atmosphere of $8 \% \mathrm{CO}_{2}$ for $18-22 \mathrm{~h}$, shaking at $37{ }^{\circ} \mathrm{C}$. $\triangle$ CRITICAL STEP Ensure that stock plasmid DNA concentrations are $>500 \mathrm{ng} / \mu \mathrm{L}$ and endotoxin free. Do not add ExpiFectamine CHO/plasmid DNA solution to cells quickly. This will reduce titers.

(xi) Adding enhancers. For small-scale experiments, add $150 \mu \mathrm{L}$ of ExpiFectamine $\mathrm{CHO}$ Enhancer and $6 \mathrm{~mL}$ of ExpiCHO Feed to each flask, swirling the flask gently during the 
addition. For large-scale experiments, add $4.5 \mathrm{~mL}$ of ExpiFectamine $\mathrm{CHO}$ Enhancer and $180 \mathrm{~mL}$ of ExpiCHO Feed to each flask, swirling the flask gently during the addition.

(xii) Incubate the flask in a humidified atmosphere of $5 \% \mathrm{CO}_{2}$, shaking at $32{ }^{\circ} \mathrm{C}$.

(xiii) First supernatant collection. Pour cultures into labeled conical tubes.

(xiv) Centrifuge at $500 \mathrm{~g}$ for $10 \mathrm{~min}$ at $4{ }^{\circ} \mathrm{C}$ to separate cells from the supernatant.

(xv) Transfer the protein containing supernatant to fresh, labeled conical tubes without disturbing the cell pellet.

(xvi) Resuspend the cell pellet with fresh, prewarmed ExpiCHO expression medium (29 mL for small-scale experiments and $750 \mathrm{~mL}$ for large-scale experiments), and transfer back to the original flask. Add ExpiCHO Feed to the flask (6 mL for small-scale experiments or $180 \mathrm{~mL}$ for large-scale experiments), swirling the flask gently during the addition.

(xvii) Incubate the flask in a humidified atmosphere of $5 \% \mathrm{CO}_{2}$, shaking at $32{ }^{\circ} \mathrm{C}$.

DAUSE POINT The protein containing supernatant from step (xv) can either be stored at $-80{ }^{\circ} \mathrm{C}$ to be combined with the supernatant from the day 12 collection (see below) or purified immediately.

$\triangle$ CRITICAL STEP Avoid contamination of cell cultures during supernatant removal by using aseptic technique.

(xviii) Second supernatant collection. Pour cultures into labeled conical tubes.

(xix) Centrifuge at $500 \mathrm{~g}$ for $10 \mathrm{~min}$ at $4{ }^{\circ} \mathrm{C}$ to separate cells from the supernatant.

(xx) Transfer the protein containing supernatant to fresh, labeled conical tubes without disturbing the cell pellet.

DAUSE POINT The protein containing supernatants from Step $1 \mathrm{~B}(\mathrm{xx})$ can be combined and purified or can be stored long term at $-80{ }^{\circ} \mathrm{C}$.

\section{Spike purification Timing $6 \mathrm{~h}$}

2 Purify the SARS-CoV-2 spike using either a Strep-Tactin (option A) or a Ni-NTA (option B) resin.

(A) Purification with Strep-Tactin resin Timing $\mathbf{4} \mathbf{~ h}$

(i) Add $2 \mathrm{~mL}$ of Strep-Tactin resin 50\% slurry to Poly-Prep columns (Biorad). Equilibrate the resin with $5 \mathrm{~mL}$ Strep-Tactin wash buffer (five column volumes).

(ii) Add cleared supernatant to the column. To improve spike retention, reduce the flow rate to $<3 \mathrm{~mL} \mathrm{~min}^{-1}$.

(iii) Wash the column with $5 \mathrm{~mL}$ Strep-Tactin wash buffer (five column volumes).

(iv) Add $4 \mathrm{~mL}$ Strep-Tactin elution buffer for protein elution, and collect eluate in a single tube.

(v) Concentrate the eluate in a $30 \mathrm{kDa}$ cutoff spin concentrator (Amicon Ultra-15) at 4,000g for $5 \mathrm{~min}\left(4^{\circ} \mathrm{C}\right.$ ) or until concentrated to $\sim 5 \mathrm{mg} \mathrm{mL}^{-1}$ (maximum $10 \mathrm{mg} \mathrm{mL}^{-1}$ ) or below $500 \mu \mathrm{L}$ if the protein will be further separated via size exclusion chromatography. Aliquot and store at $-80{ }^{\circ} \mathrm{C}$ in Superose 6 SEC Buffer, or continue to the size exclusion chromatography step.

(B) Purification with Ni-NTA resin Timing $\mathbf{4} \mathbf{h}$

(i) Add $2 \mathrm{~mL}$ of Ni-NTA resin slurry (50\% beads in $30 \%$ ethanol) to Poly-Prep Columns (Biorad). Equilibrate the resin with $5 \mathrm{~mL}$ Ni-NTA wash buffer (five column volumes).

(ii) Supplement cleared supernatant with $10 \mathrm{mM}$ imidazole, and add to the column for protein binding. Reduce the flow rate to $<3 \mathrm{~mL} / \mathrm{min}$ to improve spike retention.

(iii) Wash the column with $5 \mathrm{~mL}$ Ni-NTA wash buffer (five column volumes).

(iv) Add $4 \mathrm{~mL} \mathrm{Ni-NTA} \mathrm{elution} \mathrm{buffer} \mathrm{for} \mathrm{protein} \mathrm{elution,} \mathrm{and} \mathrm{collect} \mathrm{eluate.}$

(v) Concentrate the eluate in a $30 \mathrm{kDa}$ cutoff spin concentrator (Amicon Ultra-15) at 4,000g for $5 \mathrm{~min}\left(4^{\circ} \mathrm{C}\right.$ ) or until concentrated to $\sim 5 \mathrm{mg} \mathrm{mL}^{-1}$ (maximum $10 \mathrm{mg} \mathrm{mL}^{-1}$ ) or below $500 \mu \mathrm{L}$ if the protein will be further separated via size exclusion chromatography. Aliquot and store at $-80{ }^{\circ} \mathrm{C}$ in Superose 6 SEC Buffer, or continue to the size exclusion chromatography step.

? TROUBLESHOOTING

3 Equilibrate Superose 6 Column (Superose 6 Increase 10/300 GL, GE) on a fast protein liquid chromatograph with $>1$ column volume of Superose 6 SEC buffer.

4 Load purified spike protein into a $500 \mu \mathrm{L}$ loop. Inject the sample at $0.5 \mathrm{~mL} / \mathrm{min}$. Collect $0.5 \mathrm{~mL}$ fractions.

5 Pool peak fractions based on the chromatogram. Peak fraction should elute between 13 and $14 \mathrm{~mL}$. 
6 Concentrate the eluate in a $30 \mathrm{kDa}$ cutoff spin concentrator (Amicon Ultra-15) at 4,000 $\mathrm{g}$ for $5 \mathrm{~min}$ $\left(4{ }^{\circ} \mathrm{C}\right.$ ) or until concentrated to $\sim 5 \mathrm{mg} \mathrm{mL}^{-1}$ (maximum $10 \mathrm{mg} \mathrm{mL}^{-1}$ ). Aliquot and store at $-80{ }^{\circ} \mathrm{C}$, or continue to thermostability assay.

PAUSE POINT Concentrated protein can be flash frozen in liquid nitrogen. Plan to minimize freeze-thaw cycles. We recommend only a single freeze-thaw cycle and to store concentration protein for downstream assays or size exclusion chromatography.

(Optional) Thermostability assay Timing $2 \mathrm{~h}$

7 Dilute spike protein to a final concentration of $0.25 \mathrm{mg} / \mathrm{mL}$, and deposit $15 \mu \mathrm{L}$ per well into a MicroAmp Fast 96-Well Reaction Plate $(0.1 \mathrm{~mL})$. Plan to have enough protein for at least three replicates per sample.

8 Create a SYPRO Orange solution by diluting the $5,000 \times$ stock to $20 \times(0.5 \mu \mathrm{L}$ in $125 \mu \mathrm{L}$ buffer $)$. Make sure that your SYPRO Orange dilution buffer matches your protein buffer.

9 Inject $5 \mu \mathrm{L}$ of $20 \times$ SYPRO Orange into each protein-containing well for a final concentration of $1 \times$ spike, $5 \times$ SYPRO Orange and a volume of $20 \mu \mathrm{L}$.

10 Cover the plate using an optical adhesive cover, and gently vortex for $\sim 15 \mathrm{~s}$. Once the plate has been adequately mixed, centrifuge to eliminate any air bubbles (600 $\mathrm{rcf}$ for $3 \mathrm{~min}$ ).

11 Perform continuous fluorescence measurements $\left(\lambda_{\mathrm{ex}}=465 \mathrm{~nm}, \lambda_{\mathrm{em}}=580 \mathrm{~nm}\right)$ on differential scanning fluorimetry, using a ramp rate of $4{ }^{\circ} \mathrm{C} / \mathrm{min}$ from $25^{\circ} \mathrm{C}$ to $95{ }^{\circ} \mathrm{C}$.

\section{(Optional) Bio-layer interferometry Timing $3 \mathrm{~h}$}

12 Set instrument parameters with a shaking rate of $1,000 \mathrm{rpm}$ at $25^{\circ} \mathrm{C}$, although higher temperatures can also be used as necessary.

13 Dilute spike variants to $10 \mathrm{nM}$. Serial dilute ACE2 to $200 \mathrm{nM}, 100 \mathrm{nM}, 50 \mathrm{nM}$ and $25 \mathrm{nM}$ in buffer. Include a well without ACE2 as a reference.

14 Immerse SA sensor tips in BLI buffer for at least $600 \mathrm{~s}$. ? TROUBLESHOOTING

15 Immobilize spike variants on the tips until 0.6 response $(\mathrm{nm})$ is achieved, and move to the next step.

16 Equilibrate spike-binding tips in BLI buffer for $60 \mathrm{~s}$.

17 Move the sensor tips to the wells with indicated concentrations of ACE2, and immerse for $600 \mathrm{~s}$ for the association step. Include a well with no ACE2 as reference.

? TROUBLESHOOTING

18 Move the sensor tips to other wells containing BLI buffer and immerse for $600 \mathrm{~s}$ as the dissociation step.

19 Subtract all the data with reference sensor, and align curves to the baseline.

20 Fit the curves globally with a 1:1 binding model. Care should be taken to use an appropriate model when fitting antibody binding curves because these also include additional avidity effects. To aid further experiment design, we direct the reader to several excellent BLI reviews and methods ${ }^{70-72}$.

\section{(Optional) Enzyme-linked immunosorbent assays Timing $2 \mathrm{~d}$}

! CAUTION Handle patient serum (or plasma) using universal precautions for the prevention of bloodborne pathogens. Work should be performed in a biosafety level 2 rated laboratory while wearing personal protective equipment such as gloves and safety glasses.

21 Prepare coating antigens (SARS-CoV-2 spike ectodomain and SARS-CoV-2 RBD) at $2 \mu \mathrm{g} / \mathrm{mL}$ in PBS ( $\mathrm{pH} 7.5$ ), and add $50 \mu \mathrm{L} /$ well to a 96-well assay plate (high-binding polystyrene, Corning, cat. no. 3361).

22 Incubate at $4{ }^{\circ} \mathrm{C}$, shaking at $100 \mathrm{rpm}(2 \mathrm{~mm}$ orbital shaker $)$ overnight.

23 Discard coating antigen, and blot plate dry on paper towels. Dispense $200 \mu \mathrm{L} /$ well of $2 \%$ milk in PBS, and block plate at RT for $2 \mathrm{~h}$.

24 Wash plate three times with $300 \mu \mathrm{L} /$ well of PBST (PBS with $0.1 \%$ Tween 20 ).

25 Add $50 \mu \mathrm{L} /$ well PBSMT (1\% milk in PBS, 0.05\% Tween 20) to blocked plate.

26 Prepare samples, along with a negative serum control (for our study, we used donor GNEG from July 2019) and positive control mAb or serum, in a separate PCR plate by adding $6 \mu \mathrm{L}$ of serum to $94 \mu \mathrm{L}$ of PBSMT (1:16.7). Prepare positive control mAb similarly by diluting in PBSMT to desired concentration (for our study, we used mAb CR3022 at $9 \mu \mathrm{g} / \mathrm{mL}$ ).

27 Mix samples by pipetting up and down, and spin down plate at RT for 2 min at 4,000g.

28 Serially dilute samples using a multichannel pipette to transfer $25 \mu \mathrm{L}$ of each sample from PCR plate into the initial dilution series on the ELISA plate (e.g., row A-first dilution at 1:50 serum 

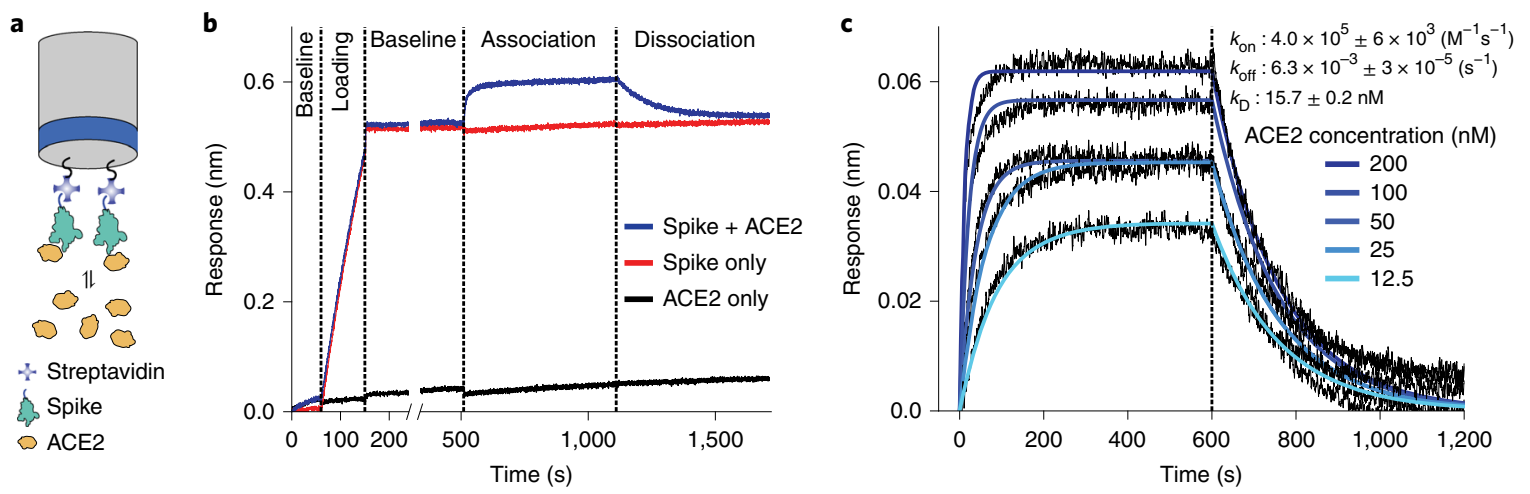

Fig. 3 | BLI analysis of spike-ACE2 binding. a, Schematic of the BLI experiment. Recombinant spikes with a C-terminal TwinStrep epitope are immobilized on a SA-coated tip. Association and dissociation of ACE2 is measured over time. b. Stepwise preparation of the BLI tip. Highest response is visualized with pre-binding spike and challenging with ACE2. c, Determination of the association $\left(k_{\mathrm{on}}\right)$ and dissociation $\left(k_{\text {off }}\right)$ constants of spike for ACE2.
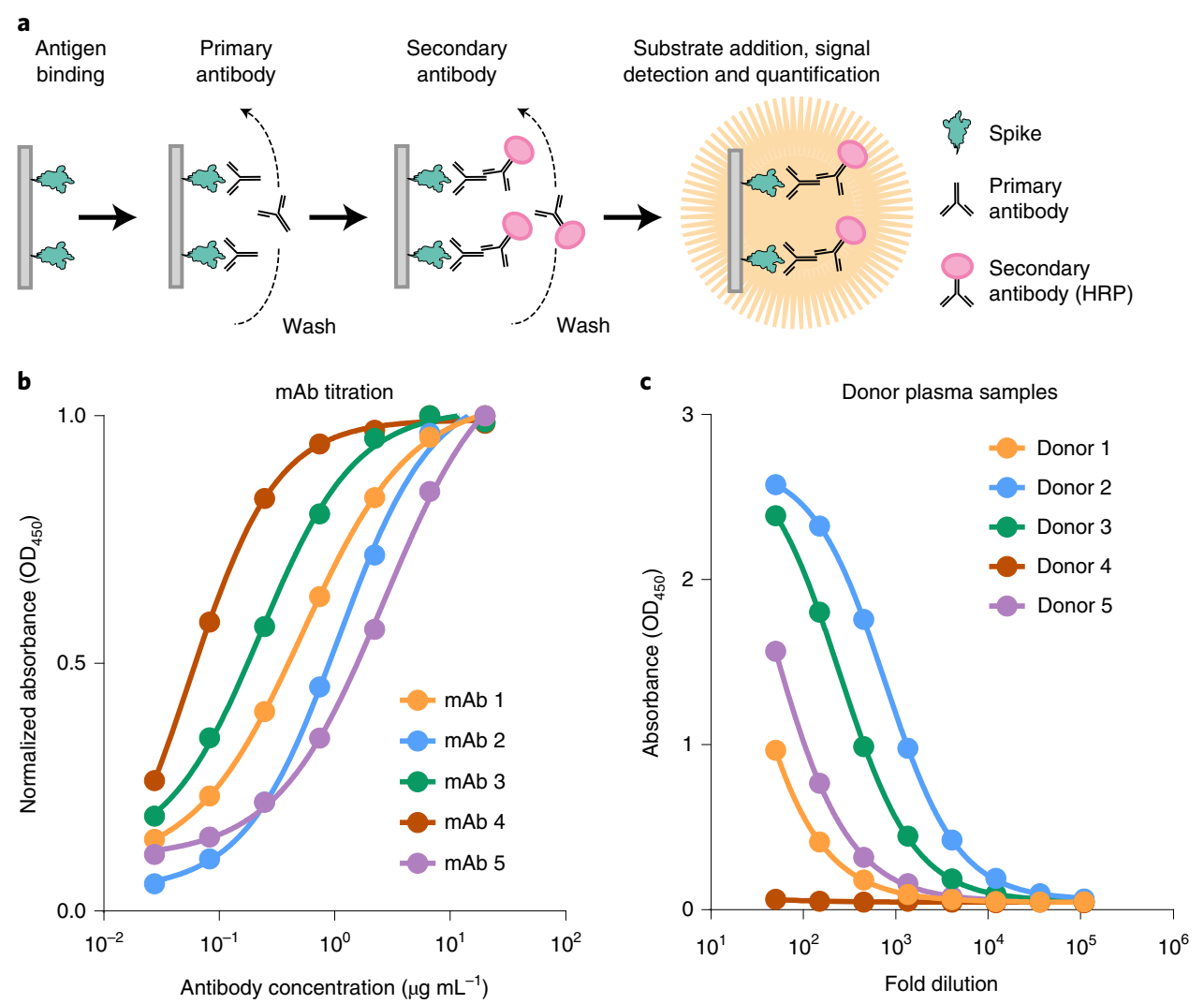

Fig. 4 | ELISA of monoclonal antibodies and patient serum. a, An indirect ELISA used for spike detection. b, Binding profile of five purified $m A$ bs against the spike trimer. c, Binding profile of five donor plasma samples against the spike trimer.

in PBSMT). Pipette up and down ten times to mix, and transfer $25 \mu \mathrm{L}$ into the next row, repeating process to serially dilute samples threefold per series across the ELISA plate.

$\triangle$ CRITICAL STEP Pipette serial dilutions with care to avoid propagating error. Allow HRP substrate to reach RT prior to use. Do not use cold HRP substrate.

29 Incubate plate at RT for $1 \mathrm{~h}$ for binding.

30 After binding, wash plate three times with $300 \mu \mathrm{L} /$ well of PBST.

31 Prepare anti-human IgG Fab HRP (Sigma A0293) at 1:5,000 dilution in PBSTM. Add this secondary antibody working solution to plate at $50 \mu \mathrm{L} /$ well. 
32 Incubate at RT for $30 \mathrm{~min}$. During this incubation, warm up substrate reagent 1-Step Ultra TMB ELISA substrate (Thermo Fisher Scientific, cat. no. 34028) to RT (5 mL substrate/ELISA plate).

$\triangle$ CRITICAL STEP Allow HRP substrate to reach RT prior to use. Do not use cold HRP substrate.

33 Wash plate three times with $300 \mu \mathrm{L} /$ well of PBST.

34 Add RT ELISA substrate reagent to plate at $50 \mu \mathrm{L} /$ well.

35 Develop plate until top dilutions approach dark-blue saturation point (1-5 min typically).

36 Quench plate development by adding $50 \mu \mathrm{L}$ /well of $4 \mathrm{M} \mathrm{H}_{2} \mathrm{SO}_{4}$.

! CAUTION Handle concentrated acid with caution.

37 Immediately transfer plate to a plate reader, and read at $450 \mathrm{~nm}$.

? TROUBLESHOOTING

\section{Anticipated results}

By following the procedures in this protocol (outlined in Fig. 2a), users can express, purify and characterize recombinant spike for downstream studies in $\sim 1$ week. We routinely produce $\sim 10 \mathrm{mg} / \mathrm{L}$ and $\sim 30 \mathrm{mg} / \mathrm{L}$ of HexaPro in FreeStyle 293-F and ExpiCHO-S cells, respectively; representing a tenfold increase in expression from S-2P. We quantify spike purity on SDS-PAGE gels (Fig. 2b). In our experience, a monodisperse peak on a size exclusion column indicates a homogeneous and trimeric spike (Fig. 2c). Negative-stain electron microscopy images confirmed the trimeric status (Fig. 2e,f). Recombinant spike and its circulating variants are essential for understanding the basic biology of SARS-CoV-2 (Fig. 3) and for diagnostic assays (Fig. 4). More broadly, this protocol will be widely useful to researchers studying other trimeric class 1 fusion proteins.

\section{Troubleshooting}

Troubleshooting advice can be found in Table 2 .

\begin{tabular}{|c|c|c|c|}
\hline Step & Problem & Possible reason & Possible solution \\
\hline 1 & Cell culture contamination & Improper aseptic technique & $\begin{array}{l}\text { Regularly check cultures for bacterial or fungal } \\
\text { contamination. This can be done by observing cultures } \\
\text { under a light microscope. Commercial mycoplasma } \\
\text { detection kits should be used regularly. To prevent } \\
\text { contaminations, use strict aseptic technique }\end{array}$ \\
\hline $1 \mathrm{~A}(\mathrm{iii})$ & Poor transfection efficiency & $\begin{array}{l}\text { FreeStyle 293-F suspension are } \\
\text { clustering }\end{array}$ & $\begin{array}{l}\text { Vigorously vortex cells for } 20-30 \text { s to obtain cultures } \\
\text { composed predominantly of single cells }\end{array}$ \\
\hline \multirow[t]{2}{*}{ 1B(ii) } & \multirow[t]{2}{*}{$\begin{array}{l}\text { Cells appear excessively } \\
\text { clumpy or stringy }\end{array}$} & \multirow[t]{2}{*}{$\begin{array}{l}\text { Cells are in stationary phase or } \\
\text { have low viability }\end{array}$} & $\begin{array}{l}\text { Ensure cells are in early log-phase growth }\left(1.5-3 \times 10^{5}\right. \\
\text { cells } / \mathrm{mL}) \text { to avoid long doubling times and low titers }\end{array}$ \\
\hline & & & $\begin{array}{l}\text { If cells have low viability, thaw out fresh cells and } \\
\text { ensure viability is }>95 \%\end{array}$ \\
\hline \multirow[t]{2}{*}{2} & \multirow[t]{2}{*}{$\begin{array}{l}\text { No detectable protein after } \\
\text { purification }\end{array}$} & Low protein expression & $\begin{array}{l}\text { Run a western blot to detect spike in the supernatant. } \\
\text { Confirm that cells have }>95 \% \text { viability. We observe low } \\
\text { yields with older cells }\end{array}$ \\
\hline & & $\begin{array}{l}\text { Protein not properly eluted } \\
\text { from resin }\end{array}$ & $\begin{array}{l}\text { Boil purification resin in } 1 \times \text { Laemmli buffer, spin } \\
\text { down debris, and run the supernatant on an SDS-PAGE } \\
\text { gel. If protein is present, increase the concentration } \\
\text { of D-desthiobiotin or imidazole. Multiple purification } \\
\text { tags on trimeric spike increases affinity for the resin }\end{array}$ \\
\hline 14 & No spike loading & $\begin{array}{l}\text { Low/inaccurate concentration of } \\
\text { spike or the protein has degraded }\end{array}$ & $\begin{array}{l}\text { Increase/remeasure spike concentration. Run an SDS- } \\
\text { PAGE to check if full-length spike is expressed }\end{array}$ \\
\hline 17 & Nonspecific binding of analytes & $\begin{array}{l}\text { Insufficient blocking reagent and } \\
\text { detergent }\end{array}$ & Increase the concentration of BSA and detergent \\
\hline 37 & $\begin{array}{l}\text { Inaccurate or inconsistent } \\
\text { plate readings }\end{array}$ & $\begin{array}{l}\text { Precipitate may form over time } \\
\text { after } \mathrm{H}_{2} \mathrm{SO}_{4} \text { addition }\end{array}$ & Immediately read plate at $450 \mathrm{~nm}$ \\
\hline
\end{tabular}




\section{Timing}

Step 1, cell culture and spike expression: 6-14 d

A, expression in FreeStyle 293-F cells: 6 d

i-ii, cell seeding: $20 \mathrm{~min}$

iii-viii, cell transfection: $4 \mathrm{~h}$

ix-xiii, cell collection: $1 \mathrm{~h}$

B, expression in ExpiCHO-S cells: $14 \mathrm{~d}$

i-ii, cell seeding: 20 min

iii- $\mathrm{x}$, cell transfection: $4 \mathrm{~h}$

xi-xii, adding enhancers: $20 \mathrm{~min}$

xiii-xvii, first supernatant collection: $30 \mathrm{~min}$

xviii-xx, second supernatant collection: $30 \mathrm{~min}$

Steps 2-6, spike purification, $6 \mathrm{~h}$

A, purification with Strep-Tactin resin: $4 \mathrm{~h}$

B, purification with Ni-NTA resin: $4 \mathrm{~h}$

Steps 7-11, thermostability assay, $2 \mathrm{~h}$

Steps 12-20, BLI, $3 \mathrm{~h}$

Steps 21-37, ELISA, 2 d

\section{Reporting Summary}

Further information on research design is available in the Nature Research Reporting Summary linked to this article.

\section{Data availability}

The data presented in these figures were generated as part of ref. ${ }^{36}$. Raw files associated with Fig. 3 are available from the corresponding author upon request.

\section{References}

1. Kim, D. et al. The architecture of SARS-CoV-2 transcriptome. Cell 181, 914-921.e10 (2020).

2. Finkel, Y. et al. The coding capacity of SARS-CoV-2. Nature https://doi.org/10.1038/s41586-020-2739-1 (2020).

3. Ullrich, S. \& Nitsche, C. The SARS-CoV-2 main protease as drug target. Bioorg. Med. Chem. Lett. 30, 127377 (2020).

4. Buchholz, U. J. et al. Contributions of the structural proteins of severe acute respiratory syndrome coronavirus to protective immunity. Proc. Natl Acad. Sci. USA 101, 9804-9809 (2004).

5. Gavor, E., Choong, Y. K., Er, S. Y., Sivaraman, H. \& Sivaraman, J. Structural basis of SARS-CoV-2 and SARS-CoV antibody interactions. Trends Immunol. 41, 1006-1022 (2020).

6. Jeyanathan, M. et al. Immunological considerations for COVID-19 vaccine strategies. Nat. Rev. Immunol. 20, 615-632 (2020).

7. Ke, Z. et al. Structures and distributions of SARS-CoV-2 spike proteins on intact virions. Nature https://doi.org/10.1038/s41586-020-2665-2 (2020).

8. Turoňová, B. et al. In situ structural analysis of SARS-CoV-2 spike reveals flexibility mediated by three hinges. Science https://doi.org/10.1126/science.abd5223 (2020).

9. Klein, S. et al. SARS-CoV-2 structure and replication characterized by in situ cryo-electron tomography. Nat. Commun. 11, 5885 (2020).

10. Yao, H. et al. Molecular architecture of the SARS-CoV-2 virus. Cell 183, 730-738.e13 (2020).

11. Neuman, B. W. et al. A structural analysis of M protein in coronavirus assembly and morphology. J. Struct. Biol. 174, 11-22 (2011).

12. Hoffmann, M., Kleine-Weber, H. \& Pöhlmann, S. A multibasic cleavage site in the spike protein of SARS-CoV-2 is essential for infection of human lung cells. Mol. Cell 78, 779-784.e5 (2020).

13. Coutard, B. et al. The spike glycoprotein of the new coronavirus $2019-\mathrm{nCoV}$ contains a furin-like cleavage site absent in CoV of the same clade. Antivir. Res. 176, 104742 (2020).

14. Wrobel, A. G. et al. SARS-CoV-2 and bat RaTG13 spike glycoprotein structures inform on virus evolution and furin-cleavage effects. Nat. Struct. Mol. Biol. 27, 763-767 (2020).

15. Papa, G. et al. Furin cleavage of SARS-CoV-2 spike promotes but is not essential for infection and cell-cell fusion. PloS Pathog. 17, e1009246 (2021).

16. Shang, J. et al. Cell entry mechanisms of SARS-CoV-2. Proc. Natl Acad. Sci. USA 117, 11727-11734 (2020).

17. Belouzard, S., Chu, V. C. \& Whittaker, G. R. Activation of the SARS coronavirus spike protein via sequential proteolytic cleavage at two distinct sites. Proc. Natl Acad. Sci. USA 106, 5871-5876 (2009).

18. Cai, Y. et al. Distinct conformational states of SARS-CoV-2 spike protein. Science 369, 1586-1592 (2020). 
19. Wrapp, D. et al. Cryo-EM structure of the 2019-nCoV spike in the prefusion conformation. Science 367, 1260-1263 (2020).

20. Walls, A. C. et al. Structure, function, and antigenicity of the SARS-CoV-2 spike glycoprotein. Cell 181, 281-292.e6 (2020).

21. Henderson, R. et al. Controlling the SARS-CoV-2 spike glycoprotein conformation. Nat. Struct. Mol. Biol. 27, 925-933 (2020).

22. Lan, J. et al. Structure of the SARS-CoV-2 spike receptor-binding domain bound to the ACE2 receptor. Nature 581, 215-220 (2020).

23. Yan, R. et al. Structural basis for the recognition of SARS-CoV-2 by full-length human ACE2. Science 367, 1444-1448 (2020).

24. Benton, D. J. et al. Receptor binding and priming of the spike protein of SARS-CoV-2 for membrane fusion. Nature 588, 327-330 (2020).

25. Zhou, T. et al. Cryo-EM structures of SARS-CoV-2 spike without and with ACE2 reveal a pH-dependent switch to mediate endosomal positioning of receptor-binding domains. Cell Host Microbe 28, 867-879.e5 (2020).

26. Yi, C. et al. Key residues of the receptor binding motif in the spike protein of SARS-CoV-2 that interact with ACE2 and neutralizing antibodies. Cell Mol. Immunol. 17, 621-630 (2020).

27. Shang, J. et al. Structural basis of receptor recognition by SARS-CoV-2. Nature 581, 221-224 (2020).

28. Huang, Y., Yang, C., Xu, X.-F., Xu, W. \& Liu, S.-W. Structural and functional properties of SARS-CoV-2 spike protein: potential antivirus drug development for COVID-19. Acta Pharmacol. Sin. 41, 1141-1149 (2020).

29. Sternberg, A. \& Naujokat, C. Structural features of coronavirus SARS-CoV-2 spike protein: targets for vaccination. Life Sci. 257, 118056 (2020).

30. Chen, J., Gao, K., Wang, R., Nguyen, D. D. \& Wei, G.-W. Review of COVID-19 antibody therapies. Annu. Rev. Biophys. https://doi.org/10.1146/annurev-biophys-062920-063711 (2020).

31. Tay, M. Z., Poh, C. M., Rénia, L., MacAry, P. A. \& Ng, L. F. P. The trinity of COVID-19: immunity, inflammation and intervention. Nat. Rev. Immunol. 20, 363-374 (2020).

32. Pallesen, J. et al. Immunogenicity and structures of a rationally designed prefusion MERS-CoV spike antigen. Proc. Natl Acad. Sci. USA 114, E7348-E7357 (2017).

33. Kirchdoerfer, R. N. et al. Pre-fusion structure of a human coronavirus spike protein. Nature 531, 118-121 (2016).

34. Walls, A. C. et al. Cryo-electron microscopy structure of a coronavirus spike glycoprotein trimer. Nature 531, 114-117 (2016).

35. Walls, A. C. et al. Glycan shield and epitope masking of a coronavirus spike protein observed by cryo-electron microscopy. Nat. Struct. Mol. Biol. 23, 899-905 (2016).

36. Hsieh, C.-L. et al. Structure-based design of prefusion-stabilized SARS-CoV-2 spikes. Science https://doi.org/10.1126/science.abd0826 (2020).

37. Costello, S. M. et al. The SARS-CoV-2 spike reversibly samples an open-trimer conformation exposing novel epitopes. Preprint at bioRxiv https://doi.org/10.1101/2021.07.11.451855 (2021).

38. Huang, Y. et al. Identification of a conserved neutralizing epitope present on spike proteins from all highly pathogenic coronaviruses. Preprint at bioRxiv https://doi.org/10.1101/2021.01.31.428824 (2021).

39. Javanmardi, K. et al. Rapid characterization of spike variants via mammalian cell surface display. Preprint at bioRxiv https://doi.org/10.1101/2021.03.30.437622 (2021).

40. Long, S. W. et al. Molecular architecture of early dissemination and massive second wave of the SARS-CoV-2 virus in a major metropolitan area. mBio 11, e02707-20 (2020).

41. Sun, Z. et al. Mass spectrometry analysis of newly emerging coronavirus HCoV-19 spike protein and human ACE2 reveals camouflaging glycans and unique post-translational modifications. Engineering (Beijing) https://doi.org/10.1016/j.eng.2020.07.014 (2020).

42. Amanat, F. et al. A serological assay to detect SARS-CoV-2 seroconversion in humans. Nat. Med. 26, 1033-1036 (2020).

43. Crawford, K. H. D. et al. Dynamics of neutralizing antibody titers in the months after SARS-CoV-2 infection. J. Infect. Dis. https://doi.org/10.1093/infdis/jiaa618 (2020).

44. Rogers, T. F. et al. Isolation of potent SARS-CoV-2 neutralizing antibodies and protection from disease in a small animal model. Science 369, 956-963 (2020).

45. Chi, X. et al. A neutralizing human antibody binds to the $\mathrm{N}$-terminal domain of the Spike protein of SARS-CoV-2. Science 369, 650-655 (2020).

46. Liu, L. et al. Potent neutralizing antibodies against multiple epitopes on SARS-CoV-2 spike. Nature 584, 450-456 (2020).

47. Wec, A. Z. et al. Broad neutralization of SARS-related viruses by human monoclonal antibodies. Science 369, 731-736 (2020).

48. Zheng, Z. et al. Monoclonal antibodies for the S2 subunit of spike of SARS-CoV-1 cross-react with the newlyemerged SARS-CoV-2. Euro Surveill. 25, 2000291 (2020).

49. Starr, T. N. et al. Deep mutational scanning of SARS-CoV-2 receptor binding domain reveals constraints on folding and ACE2 binding. Cell 182, 1295-1310.e20 (2020).

50. Greaney, A. J. et al. Complete mapping of mutations to the SARS-CoV-2 spike receptor-binding domain that escape antibody recognition. Cell Host Microbe 29, 44-57.e9 (2021). 
51. Jackson, L. A. et al. An mRNA vaccine against SARS-CoV-2-preliminary report. N. Engl. J. Med. https://doi.org/10.1056/NEJMoa2022483 (2020).

52. Keech, C. et al. Phase 1-2 trial of a SARS-CoV-2 recombinant spike protein nanoparticle vaccine. N. Engl. J. Med. https://doi.org/10.1056/NEJMoa2026920 (2020).

53. Juraszek, J. et al. Stabilizing the closed SARS-CoV-2 spike trimer. Nat. Commun. 12, 244 (2021).

54. Walsh, E. E. et al. Safety and immunogenicity of two RNA-based Covid-19 vaccine candidates. N. Engl. J. Med. https://doi.org/10.1056/NEJMoa2027906 (2020).

55. Bangaru, S. et al. Structural analysis of full-length SARS-CoV-2 spike protein from an advanced vaccine candidate. Science https://doi.org/10.1126/science.abe1502 (2020).

56. McCallum, M., Walls, A. C., Bowen, J. E., Corti, D. \& Veesler, D. Structure-guided covalent stabilization of coronavirus spike glycoprotein trimers in the closed conformation. Nat. Struct. Mol. Biol. 27, 942-949 (2020).

57. Xiong, X. et al. A thermostable, closed SARS-CoV-2 spike protein trimer. Nat. Struct. Mol. Biol. 27, 934-941 (2020).

58. Henderson, R. et al. Glycans on the SARS-CoV-2 spike control the receptor binding domain conformation. Preprint at bioRxiv https://doi.org/10.1101/2020.06.26.173765 (2020).

59. Gobeil, S. M.-C. et al. D614G mutation alters SARS-CoV-2 spike conformation and enhances protease cleavage at the S1/S2 junction. Cell Rep. 34, 108630 (2021).

60. Jagtap, S. et al. Evaluation of spike protein antigens for SARS-CoV-2 serology. Preprint at medRxiv https://doi.org/10.1101/2021.01.27.21250382 (2021).

61. Andersen, K. G., Rambaut, A., Lipkin, W. I., Holmes, E. C. \& Garry, R. F. The proximal origin of SARS-CoV-2. Nat. Med. 26, 450-452 (2020).

62. Shajahan, A., Supekar, N. T., Gleinich, A. S. \& Azadi, P. Deducing the N- and O-glycosylation profile of the spike protein of novel coronavirus SARS-CoV-2. Glycobiology 30, 981-988 (2020).

63. Watanabe, Y., Allen, J. D., Wrapp, D., McLellan, J. S. \& Crispin, M. Site-specific glycan analysis of the SARS-CoV-2 spike. Science https://doi.org/10.1126/science.abb9983 (2020).

64. Brun, J. et al. Analysis of SARS-CoV-2 spike glycosylation reveals shedding of a vaccine candidate. Preprint at bioRxiv https://doi.org/10.1101/2020.11.16.384594 (2020).

65. Johari, Y. B. et al. Production of trimeric SARS-CoV-2 spike protein by CHO cells for serological COVID-19 testing. Biotechnol. Bioeng. 118, 1013-1021 (2021).

66. Esposito, D. et al. Optimizing high-yield production of SARS-CoV-2 soluble spike trimers for serology assays. Protein Expr. Purif. 174, 105686 (2020).

67. Asano, N. Glycosidase inhibitors: update and perspectives on practical use. Glycobiology 13, 93R-104R (2003).

68. Elbein, A. D., Tropea, J. E., Mitchell, M. \& Kaushal, G. P. Kifunensine, a potent inhibitor of the glycoprotein processing mannosidase I. J. Biol. Chem. 265, 15599-15605 (1990).

69. Edwards, R. J. et al. Cold sensitivity of the SARS-CoV-2 spike ectodomain. Nat. Struct. Mol. Biol. https://doi.org/10.1038/s41594-020-00547-5 (2021).

70. Dzimianski, J. V. et al. Rapid and sensitive detection of SARS-CoV-2 antibodies by biolayer interferometry. Sci. Rep. 10, 21738 (2020).

71. Shah, N. B. \& Duncan, T. M. Bio-layer interferometry for measuring kinetics of protein-protein interactions and allosteric ligand effects. J. Vis. Exp. https://doi.org/10.3791/51383 (2014).

72. Kumaraswamy, S. \& Tobias, R. Label-free kinetic analysis of an antibody-antigen interaction using biolayer interferometry. Methods Mol. Biol. 1278, 165-182 (2015).

73. Olmedillas, E. et al. Structure-based design of a highly stable, covalently-linked SARS-CoV-2 spike trimer with improved structural properties and immunogenicity. Preprint at bioRxiv https://doi.org/10.1101/2021. 05.06.441046 (2021).

\section{Acknowledgements}

We thank members of the Maynard, Finkelstein and McLellan Laboratories for providing helpful comments on the manuscript. This work was supported by NIH grant R01-AI127521 (J.S.M.), GM120554 and GM124141 (I.J.F.); the Bill \& Melinda Gates Foundation INV017592 (J.A.M., I.J.F. and J.S.M.); Welch Foundation grants F-1767 (J.A.M.) and F-1808 (I.J.F.); and the NSF 1453358 to (I.J.F.). I.J.F. is a CPRIT Scholar in Cancer Research. This research has been funded in part with federal funds under a contract from the National Institute of Allergy and Infectious Diseases, National Institutes of Health, contract number 75N93019C00050 (G.C.I.). This research was, in part, supported by the National Cancer Institute's National Cryo-EM Facility at the Frederick National Laboratory for Cancer Research under contract HSSN261200800001E. The Sauer Structural Biology Laboratory is supported by the University of Texas College of Natural Sciences and by award RR160023 from the Cancer Prevention and Research Institute of Texas (CPRIT).

\section{Author contributions}

All coauthors contributed to HexaPro design, purification and characterization. J.M.S., C.-W.C., H.-C.K., K.J. and I.J.F. wrote the protocol with input from all coauthors.

\section{Competing interests}

N.W. and J.S.M. are inventors on US patent application no. 62/412,703 ('Prefusion Coronavirus Spike Proteins and Their Use'). D.W., N.W. and J.S.M. are inventors on US patent application no. 62/972,886 ('2019-nCoV Vaccine'). C.-L.H., J.A.G., J.M.S., C.-W.C., A.M.D., K.J., H.-C.K., D.W., P.O.B., C.K.H., N.V.J., N.W., J.A.M., I.J.F. and J.S.M. are inventors on US patent application no. 63/032,502 ('Engineered Coronavirus Spike (S) Protein and Methods of Use Thereof'). 


\section{Additional information}

Supplementary information The online version contains supplementary material available at https://doi.org/10.1038/s41596-021-00623-0. Correspondence and requests for materials should be addressed to Ilya J. Finkelstein.

Peer review information Nature Protocols thanks the anonymous reviewers for their contribution to the peer review of this work. Reprints and permissions information is available at www.nature.com/reprints.

Publisher's note Springer Nature remains neutral with regard to jurisdictional claims in published maps and institutional affiliations.

Received: 21 December 2020; Accepted: 6 September 2021;

Published online: 5 October 2021

\section{Related links}

Key references using this protocol

Hsieh, C. L. et al. Science 369, 1501-1505 (2020): https://doi.org/10.1126/science.abd0826

Javanmardi, K. et al. Preprint at bioRxiv (2021): https://doi.org/10.1101/2021.03.30.437622

Huang, Y. et al. Preprint at bioRxiv (2021): https://doi.org/10.1101/2021.01.31.428824 


\section{Reporting Summary}

Nature Research wishes to improve the reproducibility of the work that we publish. This form provides structure for consistency and transparency in reporting. For further information on Nature Research policies, see our Editorial Policies and the Editorial Policy Checklist.

\section{Statistics}

For all statistical analyses, confirm that the following items are present in the figure legend, table legend, main text, or Methods section.

n/a Confirmed

Х $\square$ The exact sample size $(n)$ for each experimental group/condition, given as a discrete number and unit of measurement

Х $\square$ A statement on whether measurements were taken from distinct samples or whether the same sample was measured repeatedly

$\triangle$ The statistical test(s) used AND whether they are one- or two-sided

Х Only common tests should be described solely by name; describe more complex techniques in the Methods section.

Х $\square$ A description of all covariates tested

Х $\square$ A description of any assumptions or corrections, such as tests of normality and adjustment for multiple comparisons

$\varnothing \square$ A full description of the statistical parameters including central tendency (e.g. means) or other basic estimates (e.g. regression coefficient)

$\triangle \square$ AND variation (e.g. standard deviation) or associated estimates of uncertainty (e.g. confidence intervals)

$\bigotimes \square \begin{aligned} & \text { For null hypothesis testing, the test statistic (e.g. } F, t, r \text { ) with confidence intervals, effect sizes, degrees of freedom and } P \text { value noted } \\ & \text { Give } P \text { values as exact values whenever suitable. }\end{aligned}$

Х $\square$ For Bayesian analysis, information on the choice of priors and Markov chain Monte Carlo settings

Х $\square$ For hierarchical and complex designs, identification of the appropriate level for tests and full reporting of outcomes

\ $\square$ Estimates of effect sizes (e.g. Cohen's $d$, Pearson's $r$ ), indicating how they were calculated

Our web collection on statistics for biologists contains articles on many of the points above.

\section{Software and code}

Policy information about availability of computer code

Data collection N/A

Data analysis N/A

For manuscripts utilizing custom algorithms or software that are central to the research but not yet described in published literature, software must be made available to editors and reviewers. We strongly encourage code deposition in a community repository (e.g. GitHub). See the Nature Research guidelines for submitting code \& software for further information.

\section{Data}

Policy information about availability of data

All manuscripts must include a data availability statement. This statement should provide the following information, where applicable:

- Accession codes, unique identifiers, or web links for publicly available datasets

- A list of figures that have associated raw data

- A description of any restrictions on data availability

The data presented in these figures were generated as part of ref. 36. Raw files associated with figure 3 are available from the corresponding author upon request. 


\section{Field-specific reporting}

Please select the one below that is the best fit for your research. If you are not sure, read the appropriate sections before making your selection. \Life sciences

\section{Life sciences study design}

All studies must disclose on these points even when the disclosure is negative.
Sample size N/A
Data exclusions N/A
Replication N/A
Blinding N/A

\section{Reporting for specific materials, systems and methods}

We require information from authors about some types of materials, experimental systems and methods used in many studies. Here, indicate whether each material, system or method listed is relevant to your study. If you are not sure if a list item applies to your research, read the appropriate section before selecting a response.

Materials \& experimental systems

\begin{tabular}{l|l}
\hline$n / a$ & Involved in the study \\
$\square$ & $\bigotimes$ Antibodies \\
$\square$ & $\square$ Eukaryotic cell lines \\
$\square$ & $\square$ Animals and other organisms \\
$\square$ & $\square$ Clinical data
\end{tabular}

\begin{tabular}{l|l}
\multicolumn{2}{l}{ Methods } \\
\hline n/a & Involved in the study \\
$\bigotimes$ & $\square$ ChIP-seq \\
$\searrow$ & $\square$ Flow cytometry \\
$\varnothing$ & $\square$ MRI-based neuroimaging
\end{tabular}

\section{Antibodies}

Antibodies used

CR3022 (Abcam, ab273073), anti-human IgG Fab HRP (Sigma-Aldrich, A0293)

Validation

Abcam notes CR3022 is an anti-spike S1 antibody suitable for ELISAs. Sigma-Aldrich notes anti-human IgG Fab HRP is suitable for ELISAs.

Eukaryotic cell lines

Policy information about cell lines

Cell line source(s)

FreeStyle 293-F (Gibco, R79007) and ExpiCHO-S (Gibco, A29127)

Authentication

Cell lines were purchased commercially and were not further validated.

Mycoplasma contamination

FreeStyle 293-F (Gibco, R79007) and ExpiCHO-S (Gibco, A29127) have tested negative for mycoplasma contamination.

Commonly misidentified lines

(See ICLAC register) 